University of Nebraska - Lincoln

DigitalCommons@University of Nebraska - Lincoln

USGS Staff -- Published Research

US Geological Survey

1995

Carbonate deposition, Pyramid Lake subbasin, Nevada: 2. Lake levels and polar jet stream positions reconstructed from radiocarbon ages and elevations of carbonates (tufas) deposited in the Lahontan basin

Larry Benson

U.S. Geological Survey, great.basin666@gmail.com

Michaele Kashgarian

Lawrence Livemore National Laboratory

Meyer Rubin

U.S. Geological Survey

Follow this and additional works at: https://digitalcommons.unl.edu/usgsstaffpub

Part of the Geology Commons, Oceanography and Atmospheric Sciences and Meteorology Commons, Other Earth Sciences Commons, and the Other Environmental Sciences Commons

Benson, Larry; Kashgarian, Michaele; and Rubin, Meyer, "Carbonate deposition, Pyramid Lake subbasin, Nevada: 2. Lake levels and polar jet stream positions reconstructed from radiocarbon ages and elevations of carbonates (tufas) deposited in the Lahontan basin" (1995). USGS Staff -- Published Research. 1014.

https://digitalcommons.unl.edu/usgsstaffpub/1014

This Article is brought to you for free and open access by the US Geological Survey at DigitalCommons@University of Nebraska - Lincoln. It has been accepted for inclusion in USGS Staff -- Published Research by an authorized administrator of DigitalCommons@University of Nebraska - Lincoln. 


\title{
Carbonate deposition, Pyramid Lake subbasin, Nevada: 2. Lake levels and polar jet stream positions reconstructed from radiocarbon ages and elevations of carbonates (tufas) deposited in the Lahontan basin
}

\author{
Larry Benson $^{\text {a }}$, Michaele Kashgarian ${ }^{b}$, Meyer Rubin ${ }^{\mathrm{c}}$ \\ ${ }^{a}$ U.S. Geological Survey, 3215 Marine St., Boulder, CO 80303, USA \\ ${ }^{b}$ Center for Accelerator Mass Spectrometry, Lawrence Livermore National Laboratory, P.O. Box 808, L-397, \\ Livermore, CA 94550, USA \\ ' U.S. Geological Survey, M.S. 971, 12201 Sunrise Valley Drive, Reston, VI 22092, USA
}

Received 2 August 1994; revised and accepted 11 October 1994

\begin{abstract}
Most of the tufas in the Pyramid Lake subbasin were deposited within the last 35,000 yr, including most of the mound tufas that border the existing lake. Many of the older tufas ( $>21,000$ yr B.P.) contained in the mounds were formed in association with ground-water discharge. The radiocarbon $\left({ }^{14} \mathrm{C}\right)$ ages of the older tufas represent maximum estimates of the time of their formation. Lake Lahontan experienced large and abrupt rises in level at $\sim 22,000$, 15,000 , and 11,000 yr B.P. and three abrupt recessions in level at $\sim 16,000,13,600$, and 10,000 yr B.P. The lake-level rises that were initiated at $\sim 23,500$ and 15,500 yr B.P. are believed to indicate the passage of the polar jet stream over the Lahontan basin. During expansion of the Laurentide Ice Sheet, the jet stream moved south across the basin, and during the contraction of the Ice Sheet, the jet stream moved north across the basin.

The bulk of the carbonate contained in the mound tufas was deposited during the last major lake cycle $(\sim 23,500-12,000$ yr B.P.), indicating that ground- and surface-water discharges increased at $\sim 23,500$ and decreased at $\sim 12,000$ yr B.P. A lake-level oscillation that occurred between 11,000 and $10,000 \mathrm{yr}$ B.P. is represented by a $2-\mathrm{cm}$ thick layer of dense laminated tufa that occurs at and below $1180 \mathrm{~m}$ in the low-elevation tufa mounds and at $1205 \mathrm{~m}$ in the Winnemucca Lake subbasin.
\end{abstract}

\section{Introduction}

\subsection{Previous work}

Previous studies of the Lahontan lake-level record primarily utililized the ${ }^{14} \mathrm{C}$ ages and elevations of samples of dense tufa coatings located far from suspected sites of ground-water discharge (Benson, 1993 and references therein). This procedure was implemented to avoid samples that had incorporated radioactively "dead" carbon or secondary "modern" carbon. The first form of contamination occurs when old ground water mixes with modern lake water to form a calcium carbonate precipitate; the second form of contamination occurs when modern carbon is added to a porous carbonate by a dissolution-reprecipitation process. The choice of only dense carbonates had one major shortcoming: i.e., dense tufa coatings are not distributed over the entire elevational range previously occupied by Lake Lahontan.

The sequence of formation and elevational 
distribution of carbonates in the Pyramid Lake subbasin were discussed in part 1 of this series (Benson, 1994). The most complete sequences of tufas are found in mound-like carbonate deposits that border the shore of Pyramid Lake. The sequence of tufa formation displayed in these mounds is (from oldest to youngest): (1) a beachrock containing carbonate-cemented volcanic cobbles, (2) broken and eroded old spheroids that contain thinolitic tufa and an outer rind of dense laminated tufa, (3) large cylindrical (tubular) tufas capped by (4) coatings of old dense tufas and (5) several generations of old branching tufa commonly associated with thin, platy tufas and coatings of thinolitic tufa, (6) young spheroids that contain poorly oriented young thinolitic tufa in the center and several generations of radially oriented young thinolitic tufas near the outer edge, (7) a transitional thinolite-to-branching tufa, (8) two or more layers of young branching tufa, (9) a $0.5-\mathrm{cm}$ thick layer of fine-grained dolomite, (10) a 2-cm thick layer of young dense laminated tufa, (11) a $0.1-\mathrm{cm}$ thick layer of encrusting tufa that was covered by a beach deposit and (12) a $1.0-\mathrm{cm}$ thick layer of porous encrusting tufa that coated the beach deposit and the sides of tufa mounds (See figs. 29 and 35 in Benson, 1994).

The purposes of this study are: (1) to determine the time interval over which each variety of tufa was deposited, (2) to construct a more detailed lake-level record for the Pyramid Lake subbasin for the past $30,000 \pm \mathrm{yr},(3)$ to deduce the position of the southern branch of the polar jet stream from the lake-level reconstructions, and (4) to compare Lahontan and Bonneville lake-level reconstructions.

In order to accomplish these purposes, this study incorporates $221{ }^{14} \mathrm{C}$ ages of carbon bearing materials from the Lahontan basin including: 115 previously unpublished ${ }^{14} \mathrm{C}$ ages (including 74 AMS ${ }^{14} \mathrm{C}$ ages) of mound and other tufa complexes from the Pyramid Lake subbasin, 4 previously unpublished AMS ${ }^{14} \mathrm{C}$ ages of roots associated with tufa mounds, 59 previously published ${ }^{14} \mathrm{C}$ ages of dense tufas from the Lahontan basin (Benson, 1993 and references therein), and 43 previously published ${ }^{14} \mathrm{C}$ ages of organic materials from the
Pyramid Lake and Winnemucca Lake subbasins (Thompson et al., 1986; Benson et al., 1992).

\subsection{Definitions and terms}

For the purposes of this paper, Lake Lahontan refers to any body of water existing in the Pyramid Lake subbasin prior to 10,000 yr B.P. Western Lahontan subbasins include the Pyramid Lake, Winnemucca Dry Lake, Smoke Creek-Black Rock and Honey Lake subbasins (Fig. 1). A sill is the lowest part of a divide that separates adjoining subbasins; a sill functions as a spill point when the lake in one subbasin spills to another subbasin. Change in effective wetness $\left(\Delta W_{\text {eff }}\right)$ necessary to achieve or exceed a sill elevation at steady state is defined as:

$$
\triangle W_{\text {eff }} \equiv A_{\text {paleo }} / A_{\text {hist }}
$$

where $A_{\text {paleo }}$ is the paleolake surface area and $A_{\text {hist }}$ is the mean historical surface area (corrected for anthropogenic effects). This quantitative definition of effective wetness is equivalent to the normalization of paleo-lake surface areas introduced by Benson and Paillet (1989).

Tufa varieties are classified as dense laminated, thinolitic, branching, and porous encrustations. Extensive tufa accumulations are divided into the following forms: carbonate-cemented debris (beachrock, cemented talus and cemented terraces), girdles, mounds, reefs, sheets and pendant sheets. Photographs showing examples of tufa variety and forms can be found in Benson (1994). The first occurrence of a tufa variety is termed old and the second occurrence is termed young.

Radiocarbon ages are specified as yr B.P. (years before present) and percent modern carbon is abbreviated as pmc. A sample that contains dead carbon has a ${ }^{14} \mathrm{C}: \mathrm{C}$ ratio less than modern; e.g., old ground water is said to contain dead carbon. If the ${ }^{14} \mathrm{C}$ activity of a sample is at the limit of detection, the sample is said to have an infinite age (with respect to the method of detection).

\subsection{Methods}

Sample elevations (accurate to within $\pm 3 \mathrm{~m}$ ) were obtained by hand leveling from known eleva- 


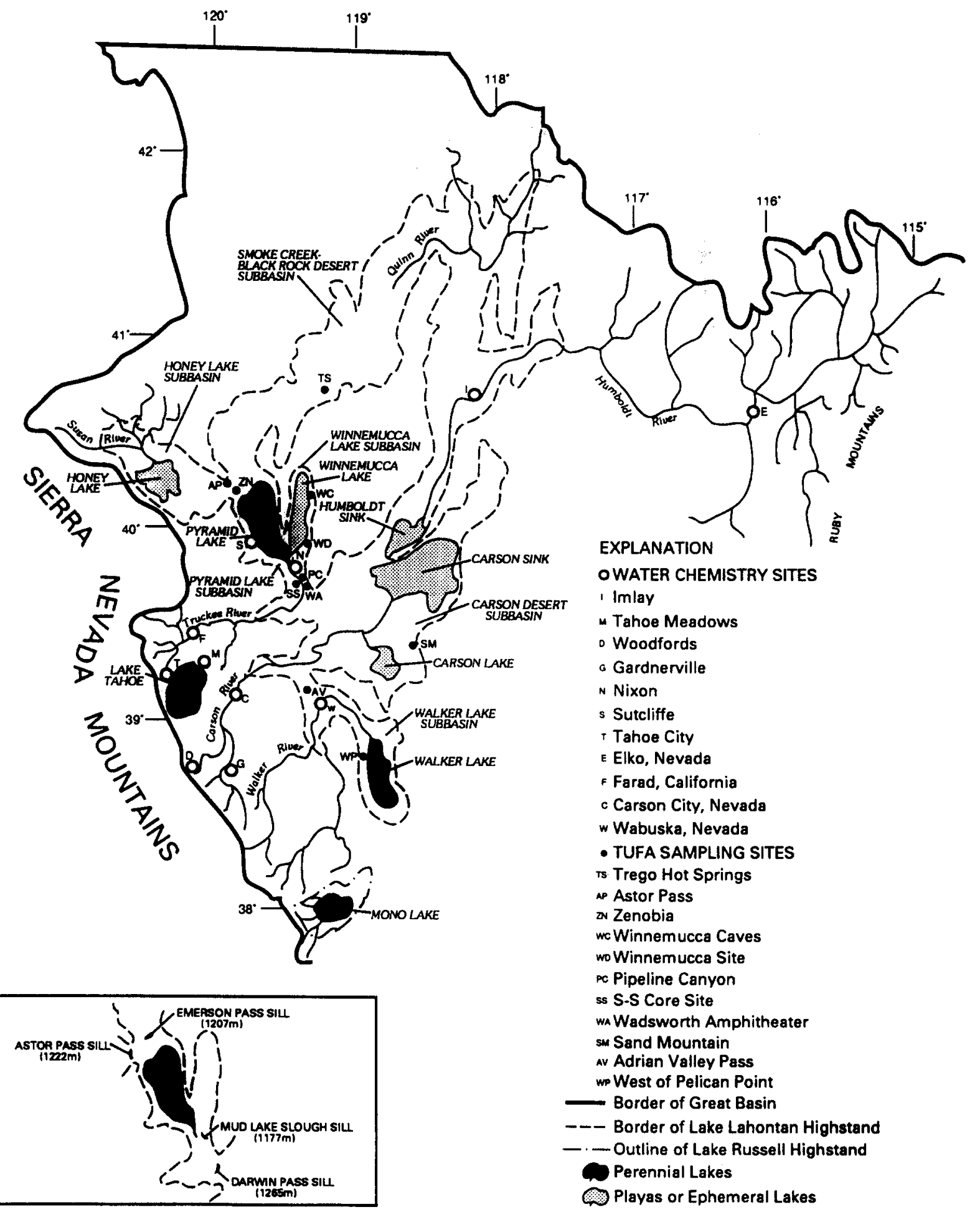

Fig. 1. Surface-water drainage for the Lahontan basin, showing location of chemistry (open circles) and tufa (filled circles) sampling sites. 
tions and with the use of a digital barometer/ altimeter referenced to a known elevation. Radiocarbon ages having a CAMS prefix are AMS ${ }^{14} \mathrm{C}$ dates obtained at the Center for Accelerator Mass Spectrometry at the Lawrence Livermore National Laboratory. All other previously unpublished radiocarbon ages were obtained by conventional counting techniques at the U.S. Geological Survey Radiocarbon Laboratory located in Reston Virginia. Ages of materials used to reconstruct lake levels are $\delta^{13} \mathrm{C}$-normalized radiocarbon ages, calculated according to the guidelines given in Stuiver and Polach (1977). Tufa $\delta^{13} \mathrm{C}$ analyses were performed at the University of Michigan and at the University of Colorado. The precision of the analyses was generally $\leqslant 0.1 \%$ and is reported relative to PDB (PeeDee Belemnite). The outer surface of each tufa sample was removed in order to eliminate surficial contamination. The densest part of each tufa was selected for $\mathrm{AMS}^{14} \mathrm{C}$ dating. Low-elevation $(<1183 \mathrm{~m})$ tufas were taken from areas that had remained covered with lake sediment until the mid 1980s and had, thereby, escaped secondary cementaion. Lao and Benson (1988) previously demonstrated that Lahontan tufa ${ }^{14} \mathrm{C}$ ages in excess of $20,000 \mathrm{yr}$ should be considered unreliable. In this study, three procedures were employed to test the reliability of ${ }^{14} \mathrm{C}$ ages of the older tufas: (1) at least two dates were obtained on each tufa sample; (2) samples of the same tufa were obtained from different locations; and (3) stratigraphic consistency of ${ }^{14} \mathrm{C}$ ages was evaluated. Samples of woody material were acid and base leached to remove soluble carbonate and decomposed organic materials prior to ${ }^{14} \mathrm{C}$ age determination.

\subsection{Surface-water hydrology and hypsography of the Lahontan basin}

The Lahontan basin consists of seven subbasins, six of which receive discharge from perennial rivers (Fig. 1). Four of the rivers (Carson, Truckee, Walker and Humboldt Rivers) contribute $\sim 96 \%$ of the total gaged surface inflow to the basin (Table 1). Mean-annual discharges of rivers emanating from the Sierra Nevada (Carson, Susan, Truckee, and Walker Rivers) are well correlated,
Table 1

Streamflow statistics for rivers that discharge to the Lahontan basin. Data taken from Benson and Paillet (1989)

\begin{tabular}{ll}
\hline River & $\begin{array}{l}\text { Mean discharge } \\
\left(\mathrm{km}^{3} \mathrm{yr}^{-1}\right)\end{array}$ \\
\hline Carson & 0.454 \\
Humboldt & 1.009 \\
Quinn & 0.036 \\
Susan & 0.085 \\
Truckee & 0.725 \\
Walker & 0.379 \\
\hline
\end{tabular}

but discharge of the Humboldt and Quinn Rivers is poorly correlated with Sierran discharge (Benson and Paillet, 1989). Diversion of some of these rivers may have played a role in regulating lake levels in Lahontan subbasins in the past; e.g., King (1978) and Davis $(1978,1982)$ described geomorphic evidence for late Quaternary diversion of the Walker and Humboldt Rivers.

There are seven sills within the Lahontan basin, including four sills that border the Pyramid Lake subbasin (Fig. 1). In the past, the level of Pyramid Lake was often regulated by spill to an adjacent subbasin. In addition the amount and direction of spill (out of or into the Pyramid Lake subbasin) was dependent on sill elevation, subbasin geometry and the amount of water discharged to each of the subbasins (Benson and Paillet, 1989). Therefore, it is not always possible to associate a unique value of $\Delta W_{\text {eff }}$ for a given lake elevation (surface area).

\section{Radiocarbon ages of surficial carbon-bearing materials from western Lahontan subbasins}

\subsection{Reliability of radiocarbon ages}

As discussed in previous papers (e.g., Benson, 1993), there are two principal sources of error in ${ }^{14} \mathrm{C}$ ages of Lahontan carbonates (Table 2): low initial ${ }^{14} \mathrm{C} / \mathrm{C}$ ratios in lake water (reservoir effect), and addition of modern carbon after precipitation of a carbonate (open system effect). In terms of the reservoir effect, Broecker and Walton (1959) found that modern (1957) materials in Pyramid 
Table 2

Elevations, radiocarbon ages, $\delta^{13} \mathrm{C}$, and $\delta^{18} \mathrm{O}$ values of carbonate deposits (tufas) from the Lake Lahontan basin [MB $=\mathrm{Marble}$ Bluff, $\mathrm{DH}=$ Doghead Rock, $\mathrm{NR}=$ Needles Rocks, $\mathrm{PP}=$ Pelican Point, $\mathrm{PR}=$ Popcorn Rocks, $\mathrm{ZN}=\mathrm{Zenobia}, \mathrm{BT}=\mathrm{Blanc}$ Tetons, $\mathrm{AP}=$ Astor Pass, $\mathrm{WC}=$ Winnemucca Caves, $\mathrm{SM}=$ Sand Mountain, $\mathrm{PC}=$ Pipeline Canyon, $\mathrm{TS}=$ Trego Hot Springs $-\mathrm{Black}$ Rock Desert, $\mathrm{TH}=$ Terraced Hills, AV $=$ Adrian Valley Pass, WP $=$ mountain west of Pelican Point in the Walker Lake subbasin, $\mathrm{SS}=$ Truckee River Canyon N of S-S Ranch, WA = Wadsworth Amphitheater on east side of Truckee River Canyon N of town of Wadsworth, Nevada, WD = outcrop in southeast corner of Winnemucca Dry Lake subbasin, PI = shore due E of Pyramid Island, $\mathrm{IR}=$ Indian Head Rock, - = no data; if no $\delta^{13} \mathrm{C}$ analyses were available, the $\delta^{13} \mathrm{C}$ value of tufa was set to $3.20 \%$ and the $\delta^{13} \mathrm{C}$ value of organic material was set to $-25 \% 0$

\begin{tabular}{llllll}
\hline $\begin{array}{l}\text { Sample } \\
\text { number }\end{array}$ & $\begin{array}{l}\text { Laboratory } \\
\text { number }\end{array}$ & Locality & $\begin{array}{l}\text { Elevation } \\
(\mathrm{m})\end{array}$ & $\begin{array}{l}{ }^{14} \mathrm{C} \text { age } \\
\text { (yr B.P.) }\end{array}$ & \pm \\
\hline
\end{tabular}

Tufa cementing talus

PL 88-1

LDGO-1723B

MB

1212

33,200

1660

(3.20)

PL88-2

LDGO-1723C

MB

50,390

Tufa lining cave

PL89-20b1

CAMS-5766

MB

1204

40,960

2270

3.05

Tubular tufa
PL90-103
PL91-502
PL90-102
PL90-114
PL90-114
PL90-116
PLPP92-9
PLPP92-9
PLPR92-21
PLPR92-2i
PLPR 92-2k
PLPR 92-2j

W-6321

W-6390

W-6389

W-6325

CAMS-5723

CAMS-6230

CAMS-5724

CAMS-6231

CAMS-6239

CAMS-5925

CAMS-3868

CAMS-3865

CAMS-3867

CAMS-3866

$\begin{array}{ll}\text { DH } & 1218.2 \\ \text { DH } & 1217.5 \\ \text { DH } & 1216.4 \\ \text { DH } & 1216.9 \\ \text { NR } & 1183 \\ \text { NR } & 1183 \\ \text { NR } & 1190 \\ \text { NR } & 1190 \\ \text { PP } & 1162 \\ \text { PP } & 1162 \\ \text { PR } & 1162 \\ \text { PR } & 1162 \\ \text { PR } & 1162 \\ \text { PR } & 1162\end{array}$

$$
\begin{aligned}
& 18,060 \\
& 20,680 \\
& 21,190 \\
& 21,910 \\
& 29,720 \\
& 30,880 \\
& 31,640 \\
& 32,410 \\
& 31,580 \\
& 34,340 \\
& 37,220 \\
& 39,060 \\
& 40,190 \\
& 41,380
\end{aligned}
$$

180
220
320
290
590
470
640
560
530
1260
860
1130
1240
1500

Old branching tufa

$\begin{array}{ll}\text { PLPR92-1 } & \text { CAMS-6241 } \\ \text { PLPR92-1 } & \text { CAMS-5927 } \\ \text { PLPP92-7 } & \text { CAMS-6234 } \\ \text { PLPP92-7 } & \text { CAMS-5924 } \\ \text { PLPP92-1 } & \text { CAMS-6233 } \\ \text { PLPP92-1 } & \text { CAMS-5923 } \\ \text { PLPP92-6t } & \text { W-6445 } \\ \text { PLPP92-6t } & \text { CAMS-5914 } \\ \text { PLPPB92-1 } & \text { CAMS-5926 } \\ \text { PLPPB92-1 } & \text { CAMS-6240 } \\ \text { PLPP92-5t } & \text { CAMS-5731 } \\ \text { PLPP92-5t } & \text { CAMS-6237 }\end{array}$

$\begin{array}{ll}\text { PR } & 1161 \\ \text { PR } & 1161 \\ \text { PP } & 1162 \\ \text { PP } & 1162 \\ \text { PP } & 1162 \\ \text { PP } & 1162 \\ \text { PP } & 1162 \\ \text { PP } & 1162 \\ \text { PP } & 1162 \\ \text { PP } & 1162 \\ \text { PP } & 1162 \\ \text { PP } & 1162\end{array}$

17,290

19,630

19,150

20,360

20,200

20,770

26,020

26,250

27,380

27,840

34,130

35,170

$\begin{array}{ll}\text { PP } & 1162 \\ \text { PP } & 1162 \\ \text { PP } & 1162 \\ \text { PP } & 1162\end{array}$

29,820

31,410

37,730

45,430

Wood coated by old branching tufa

PLPP92-6W

PLPP92-5W

PLPP92-5W 
Table 2 (continued)

\begin{tabular}{|c|c|c|c|c|c|c|}
\hline $\begin{array}{l}\text { Sample } \\
\text { number }\end{array}$ & $\begin{array}{l}\text { Laboratory } \\
\text { number }\end{array}$ & Locality & $\begin{array}{l}\text { Elevation } \\
(\mathrm{m})\end{array}$ & $\begin{array}{l}{ }^{14} \mathrm{C} \text { age } \\
\text { (yr B.P.) }\end{array}$ & $\frac{ \pm}{\text { (yr B.P.) }}$ & $\begin{array}{l}\delta^{13} \mathrm{C} \\
(\%)\end{array}$ \\
\hline \multicolumn{7}{|c|}{ Young thinolite tufa } \\
\hline PL $90-109 a$ & CAMS-5719 & BT & 1160 & 20,150 & 160 & 2.73 \\
\hline PLPP92-2 & CAMS-6017 & PP & 1162 & 20,770 & 170 & 2.93 \\
\hline \multicolumn{7}{|c|}{ Young thinolite-young branching tufa transition } \\
\hline PL90-109d & CAMS-5720 & BT & 1160 & 17,580 & 170 & 2.61 \\
\hline
\end{tabular}

Young branching tufa (includes stony, nodular, mammillary and conal tufas found in pillow- and reef-form tufa)

\begin{tabular}{|c|c|c|c|c|c|c|}
\hline PL91-601b & CAMS-5771 & MB & 1251 & 12,110 & 70 & 4.00 \\
\hline PL91-601b & W-6429 & MB & 1251 & 12,560 & 130 & 4.00 \\
\hline PLBT92-bla & CAMS-4425 & BT & 1160 & 12,520 & 90 & 3.15 \\
\hline PLBT92-blb & CAMS-4426 & BT & 1160 & 12,730 & 90 & 3.15 \\
\hline PL91-503w & CAMS-5768 & $\mathrm{DH}$ & 1217.4 & 12,590 & 90 & 3.35 \\
\hline PL91-503g & CAMS-5769 & DH & 1217.4 & 13,020 & 90 & 3.35 \\
\hline PL91-503 & W-6391 & DH & 1217.4 & 13,240 & 220 & 3.63 \\
\hline PLBT93-1e1 & CAMS-5774 & BT & 1159 & 12,770 & 90 & 3.50 \\
\hline PL90-111 & CAMS-5722 & BT & 1160 & 12,810 & 80 & 3.72 \\
\hline PL91-504 & CAMS-5770 & DH & 1216.8 & 12,910 & 80 & 3.62 \\
\hline PL91-504 & W-6393 & DH & 1216.8 & 12,980 & 150 & 3.62 \\
\hline PLBT92-b2b & CAMS-4428 & BT & 1160 & 12,930 & 90 & 3.10 \\
\hline PLBT92-b2a & CAMS-4427 & BT & 1160 & 12,940 & 90 & 3.50 \\
\hline PL91-602 & W-6430 & $\mathrm{MB}$ & 1251 & 13,000 & 150 & 3.59 \\
\hline PL89-8 & LDGO-1743p & $\mathrm{MB}$ & 1251 & 13,240 & 80 & 3.54 \\
\hline PL89-7 & LDGO-1743o & MB & 1251 & 13,390 & 80 & 3.37 \\
\hline PL90-108 & CAMS-6236 & MB & 1251 & 13,440 & 90 & 3.34 \\
\hline PL90-108 & CAMS-6235 & MB & 1251 & 13,460 & 100 & 3.34 \\
\hline PLBT93-1e2 & CAMS-5775 & BT & 1159 & 13,460 & 90 & 3.52 \\
\hline PL91-601a & W-6428 & MB & 1251 & 13,810 & 140 & 3.79 \\
\hline PL91-603 & W-6431 & MB & 1251 & 14,180 & 150 & 3.72 \\
\hline PL90-110 & CAMS-5721 & BT & 1160 & 15,730 & 140 & 2.44 \\
\hline PL91-604w & CAMS-5918 & MB & 1251 & 15,760 & 110 & 3.37 \\
\hline PL91-604g & CAMS-5917 & $\mathrm{MB}$ & 1251 & 17,510 & 150 & 3.37 \\
\hline PL91-604 & W-6432 & MB & 1251 & 17,950 & 250 & 3.37 \\
\hline PL90-107 & W-6330 & DH & 1220.7 & 15,770 & 190 & 3.01 \\
\hline PL90-106 & W-6323 & DH & 1217.5 & 16,140 & 100 & 3.52 \\
\hline PL91-605 & W-6433 & MB & 1251 & 16,600 & 220 & 3.52 \\
\hline PL91-505 & W-6394 & DH & 1218.7 & 16,700 & 210 & 3.14 \\
\hline PL91-606 & W-6434 & MB & 1251 & 16,710 & 220 & 3.45 \\
\hline PL91-506 & W-6395 & DH & 1216.9 & 17,060 & 200 & 3.32 \\
\hline PL88-4 & LDGO-1723e & MB & 1234 & 17,110 & 190 & $(3.20)$ \\
\hline PL90-101 & W-6324 & $\mathrm{DH}$ & 1216.3 & 17,850 & 130 & 3.10 \\
\hline PL90-105 & W-6322 & $\mathrm{DH}$ & 1218.5 & 18,130 & 150 & 2.85 \\
\hline PL89-5 & LDGO-1743n & MB & 1251 & 18,150 & 140 & 3.08 \\
\hline PL90-104 & W-6328 & $\mathrm{DH}$ & 1217.1 & 18,840 & 220 & 2.96 \\
\hline PL88-3 & LDGO-1723d & MB & 1234 & 18,880 & 240 & $(3.20)$ \\
\hline \multicolumn{7}{|l|}{ Chara deposits } \\
\hline PL85-2c & USGS-2171 & $\mathbf{A P}$ & 1257 & 14,640 & 160 & $(3.20)$ \\
\hline PL4c & I-9479 & $\mathrm{AP}$ & 1256 & 17,680 & 270 & (3.20) \\
\hline WDL84-3c & CL-4254140 & WC & 1230 & 18,250 & 220 & $(3.20)$ \\
\hline PL5c & I-9480 & $\mathbf{A P}$ & 1257 & 18,250 & 290 & $(3.20)$ \\
\hline
\end{tabular}


Table 2 (continued)

\begin{tabular}{|c|c|c|c|c|c|c|}
\hline $\begin{array}{l}\text { Sample } \\
\text { number }\end{array}$ & $\begin{array}{l}\text { Laboratory } \\
\text { number }\end{array}$ & Locality & $\begin{array}{l}\text { Elevation } \\
(\mathrm{m})\end{array}$ & $\begin{array}{l}{ }^{14} \mathrm{C} \text { age } \\
\text { (yr B.P.) }\end{array}$ & $\stackrel{ \pm}{(y r \text { B.P.) }}$ & $\begin{array}{l}\delta^{13} \mathrm{C} \\
(\% 0)\end{array}$ \\
\hline PL85-4c & USGS-2173 & AP & 1255 & 18,680 & 90 & $(3.20)$ \\
\hline PL3c & $\mathrm{I}-9470$ & AP & 1254 & 19,350 & 330 & $(3.20)$ \\
\hline PL85-5c & USGS-2174 & AP & 1254 & 19,520 & 90 & $(3.20)$ \\
\hline \multicolumn{7}{|c|}{ Gastropods in Chara deposits } \\
\hline WDL84-2g & CL-4254142 & WC & 1230 & 17,540 & 270 & -2.00 \\
\hline WDL84-3g & CL-4254144 & WC & 1230 & 18,180 & 640 & -1.90 \\
\hline WDL84-4g & CL-4254143 & WC & 1230 & 18,410 & 300 & -1.80 \\
\hline
\end{tabular}

Miscellaneous dense tufa coatings from between 1207 and $1308 \mathrm{~m}$

\begin{tabular}{|c|c|c|c|c|c|c|}
\hline BR84-9 & CL-4240158 & TS & 1295 & 13,010 & 230 & 3.67 \\
\hline CD84-7 & CL-4240179 & SM & 1303 & 13,130 & 150 & 3.66 \\
\hline PL112 & I-10026 & PC & 1303 & 13,360 & 200 & 3.70 \\
\hline PL111 & I-10025 & $\mathrm{MB}$ & 1277 & 13,570 & 200 & 3.71 \\
\hline BR84-8 & CL-4240157 & TS & 1270 & 14,560 & 180 & 3.50 \\
\hline BR84-5 & CL-4240154 & TS & 1238 & 15,970 & 160 & 2.96 \\
\hline PL18 & I-9328 & TH & 1267 & 16,980 & 250 & 3.30 \\
\hline BR 84-7 & CL-4240156 & TS & 1254 & 17,360 & 260 & 2.67 \\
\hline PL89-23 & W-6333 & TH & 1255 & 17,650 & 150 & 2.30 \\
\hline PL110 & I-10019 & MB & 1256 & 17,770 & 270 & 3.12 \\
\hline PL15 & I-9331 & $\mathrm{TH}$ & 1231 & 17,780 & 270 & 3.51 \\
\hline PL89-22 & W-6332 & $\mathrm{TH}$ & 1263 & 18,090 & 180 & 2.12 \\
\hline BR84-6 & CL-4240155 & TS & 1245 & 18,490 & 440 & 2.96 \\
\hline PL17 & I-9329 & $\mathrm{TH}$ & 1260 & 19,040 & 320 & 2.89 \\
\hline PL109 & I-9991 & MB & 1242 & 19,550 & 340 & 3.33 \\
\hline PL23 & $\mathrm{I}-9342$ & $\mathrm{TH}$ & 1258 & 19,980 & 360 & 3.57 \\
\hline PL44d & $\mathrm{I}-9549$ & $\mathrm{TH}$ & 1258 & 19,980 & 360 & 2.86 \\
\hline BR84-4 & CL-4240153 & TS & 1231 & 19,990 & 360 & 3.41 \\
\hline PL108 & I-10018 & MB & 1235 & 20,460 & 380 & 3.17 \\
\hline PL44b & I-9546 & $\mathrm{TH}$ & 1258 & 20,650 & 390 & 3.08 \\
\hline PL16 & I-9330 & $\mathrm{TH}$ & 1238 & 21,830 & 450 & 3.39 \\
\hline BR84-2 & CL-4240151 & TS & 1219 & 23,200 & 400 & 3.15 \\
\hline \multicolumn{7}{|c|}{ Dense tufa coatings from above $1308 \mathrm{~m}$} \\
\hline PLPC92-1 & CAMS-5930 & PC & 1325 & 12,490 & 80 & 3.46 \\
\hline PLPC92-30 & CAMS-5931 & $\mathrm{PC}$ & 1329 & 12,550 & 80 & 3.46 \\
\hline PLPC92-3i & CAMS-5932 & PC & 1329 & 12,840 & 70 & 3.39 \\
\hline PL103 & I-10002 & PC & 1321 & 13,010 & 190 & 3.45 \\
\hline PL102 & I-10001 & PC & 1312 & 13,040 & 190 & 3.38 \\
\hline PL21 & I-9326 & TH & 1325 & 13,090 & 190 & 3.69 \\
\hline PL113 & I- 10028 & $\mathrm{PC}$ & 1326 & 13,090 & 190 & 3.52 \\
\hline AV84-2 & CL-4240160 & AV & 1324 & 13,160 & 150 & 3.51 \\
\hline PL104 & I-10003 & $\mathrm{PC}$ & 1321 & 13,320 & 200 & 3.50 \\
\hline BR85-2 & USGS-2168 & TS & 1332 & 13,350 & 60 & 2.71 \\
\hline PL105 & I-10004 & $\mathrm{PC}$ & 1324 & 13,520 & 200 & 3.40 \\
\hline PL101 & I- 10000 & $\mathrm{PC}$ & 1312 & 13,600 & 200 & 3.60 \\
\hline WL101 & I-9988 & WP & 1330 & 13,810 & 210 & (3.20) \\
\hline PL41 & I-9344 & PC & 1311 & 13,890 & 210 & 3.00 \\
\hline PL20 & $\mathrm{I}-9325$ & $\mathrm{TH}$ & 1311 & 14,030 & 210 & 3.80 \\
\hline PL100 & I-9992 & $\mathrm{PC}$ & 1312 & 14,290 & 220 & 3.60 \\
\hline BR85-1 & USGS-2169 & TS & 1308 & 14,330 & 60 & 3.72 \\
\hline
\end{tabular}


Table 2 (continued)

\begin{tabular}{|c|c|c|c|c|c|c|}
\hline $\begin{array}{l}\text { Sample } \\
\text { number }\end{array}$ & $\begin{array}{l}\text { Laboratory } \\
\text { number }\end{array}$ & Locality & $\begin{array}{l}\text { Elevation } \\
(\mathrm{m})\end{array}$ & $\begin{array}{l}{ }^{14} \mathrm{C} \text { age } \\
\text { (yr B.P.) }\end{array}$ & $\begin{array}{l} \pm \\
(\mathrm{yr} \text { B.P. })\end{array}$ & $\begin{array}{l}\delta^{13} \mathrm{C} \\
(\% 0)\end{array}$ \\
\hline \multicolumn{7}{|c|}{ Tufas embedded in lake sediment } \\
\hline PLLB91-2 & W-6336 & SS & 1262 & 12,800 & 140 & 3.67 \\
\hline PLLB91-3 & CAMS-5915 & SS & 1262 & 12,900 & 80 & 3.51 \\
\hline PLLB91-3 & W-6335 & SS & 1262 & 12,960 & 150 & 3.51 \\
\hline PL87-2b & LDGO-1705b & WA & 1230 & 13,330 & 160 & 3.89 \\
\hline PL87-2a & LDGO-1705a & WA & 1230 & 13,380 & 150 & 2.59 \\
\hline PL87-2a & CAMS-5764 & WA & 1230 & 13,870 & 90 & 2.59 \\
\hline PL45 & I-9534 & WA & 1262 & 14,250 & 220 & 3.72 \\
\hline
\end{tabular}

Sucrosic tufa (dolomite)

\begin{abstract}
PLBT93-1d
PLBT92-dlb

PLBT92-d2a

PLBT92-d2b

PLBT92-d1a

PLBT92-d2a
\end{abstract}

\title{
CAMS-5773 \\ CAMS-4424 \\ CAMS-6242 \\ CAMS-4422 \\ CAMS-4423 \\ CAMS-4421
}

Young dense laminated tufa

PL90-1a

PLBT93-1a

PLBT93-1f1

WDL89-5a

PL90-1b

PL90-2a

PLBT93-1f 2

WDL89-5b

PLBT93-1b

PL90-2b

PL87-1

PLBT92-sla

WDL89-5c

PLPI93-5a

PLBT93-1c

PLBT92-s1b

PLPI93-5b

PLPI93-5d

PLPI93-5c

Encrusting tufa

PLBT91-9

PLBT91-7

PLBT91-8

PLBT91-6

PLBT91-4

Beachrock

PL40

PLND92-1

PL107

PL89-2

PL89-1
LDGO-1748a CAMS-5905

CAMS-5907

CAMS-4430

LDGO-1748b

LDGO-1748c

CAMS-5908

CAMS-4431

CAMS-5906

LDGO-1748d

LDGO-1705a

CAMS-4419

CAMS-4432

CAMS-5909

CAMS-5772

CAMS-4420

CAMS-5910

CAMS-5912

CAMS-5911

CAMS-5725

CAMS-5727

CAMS-5726

CAMS-5728

CAMS-5729

I-9347

CAMS-6014

I-10016

LDGO-1743b

LDGO-1743a
BT

BT

BT

BT

BT

BT

1159
1160
1160
1160
1160
1160

1163

1159

1159

1205

1163

1161

1159

1205

1159

1161

1164

1160

1205

1162

1159

1160

1162

1162

1162

1175

1168.1

1171.2

1167.9

1166

PR

NR

IR

IR

IR
1182

1179

1177

$$
\begin{aligned}
& 11,580 \\
& 12,030 \\
& 12,040 \\
& 12,260 \\
& 12,270 \\
& 12,370
\end{aligned}
$$

9020
9660

9770

9860

9930

9960

9970

9990

10,170

10,180

10,300

10,450

10,540

10,560

10,610

10,620

10,670

10,920

10,960

2100

2830

3450

5080

1350

1890

2110

2500

2510
80

110

80

90

120

110

3.51

3.19

3.19

3.19

3.19

3.19

0.84

0.49

0.86

1.65

0.84

0.81

0.56

0.44

0.64

0.81

(3.20)

0.48

1.26

1.10

1.39

2.61

1.92

0.63

2.03

100
80

5.11

5.16

5.32

5.68

$\begin{array}{ll}60 & 5.68 \\ 60 & 4.85\end{array}$

3.98

2.76

4.36

3.48

4.12 
Table 2 (continued)

\begin{tabular}{|c|c|c|c|c|c|c|}
\hline $\begin{array}{l}\text { Sample } \\
\text { number }\end{array}$ & $\begin{array}{l}\text { Laboratory } \\
\text { number }\end{array}$ & Locality & $\begin{array}{l}\text { Elevation } \\
(\mathrm{m})\end{array}$ & $\begin{array}{l}{ }^{14} \mathrm{C} \text { age } \\
\text { (yr B.P.) }\end{array}$ & $\begin{array}{l} \pm \\
\text { (yr B.P.) }\end{array}$ & $\begin{array}{l}\delta^{13} \mathrm{C} \\
(\%)\end{array}$ \\
\hline PL89-3 & LDGO-1743c & IR & 1182 & 2640 & 30 & 3.37 \\
\hline PL106 & I-10016 & IR & 1179 & 3590 & 90 & 4.22 \\
\hline \multicolumn{7}{|c|}{ Tufas associated with existing springs } \\
\hline PLND92-3 & CAMS-5929 & NR & 1171 & 820 & 80 & 4.76 \\
\hline PLPYR92-1 & CAMS-5928 & PI & 1160 & 1950 & 90 & -0.19 \\
\hline
\end{tabular}

and Walker Lakes had ${ }^{14} \mathrm{C}$ ages of $\sim 600$ and $\sim 150$ yr. Calculations performed by Benson (1993) indicated that the reservoir effect should range from $\sim 100$ to $\sim 400 \mathrm{yr}$ for large lakes in the Lahontan basin, having concentrations of inorganic carbon ranging from 25 to $33 \mathrm{M} \mathrm{m}^{-3}$ (moles per cubic meter) and $\mathrm{CO}_{2}$ exchange rates of 6-17 $\mathrm{M} \mathrm{m}^{-2} \mathrm{yr}^{-1}$ (Peng and Broecker 1980). In general, we expect that winds over Lahontan lakes were stronger and more persistent during glacial-age climates that existed prior to 12,000 yr B.P. (see e.g. fig. 2 in Hostetler and Benson, 1990). Windier conditions would have increased $\mathrm{CO}_{2}$ exchange rates (Erickson, 1993), thereby decreasing the magnitude of the reservoir effect. However, because there are no data on the amount of carbon dissolved in paleo-lake water, the magnitude of the paleo-reservoir effect remains conjectural.

Ground-water discharge can contribute to the magnitude of the reservoir effect. Springs occur near most tufa mounds that border Pyramid Lake (Fig. 2). Cold-water springs, especially the Popcorn Rocks and Pelican Point springs, contain relatively large concentrations of inorganic carbon (Table 3). Measurement of the ${ }^{14} \mathrm{C}$ activities of the cold and hot springs have not been made, but the ${ }^{14} \mathrm{C}$ age ( $1950 \pm 90$ yr B.P.) of tufa recently precipitated from Pyramid Island spring (PLPYR92-1, Table 2) indicates that some tufas found at mound sites (especially the tubular tufas that seem to have been associated with ground-water discharge) probably yield ${ }^{14} \mathrm{C}$ ages that exceed the actual time of deposition.

Early petrographic studies (Benson, 1978) documented that many Lahontan tufas functioned as open systems with respect to the addition of secondary carbon. Porous tufas were found to contain visible secondary material that had been acquired in either the subaquatic or the subaerial environment. Beachrock and encrusting tufa samples included in this study usually contain multiple generations of carbonate cement; therefore, the ${ }^{14} \mathrm{C}$ ages of these samples represent an integral of more than one episode of carbonate deposition. Porous tufas from the Dog Head Rock and Marble Bluff sites (Figs. 2-4) contain areas of white secondary infill. These infillings (PL91-503w and PL91-604w) have ${ }^{14} \mathrm{C}$ ages $\sim 400$ and $\sim 1800$ yr younger than the ${ }^{14} \mathrm{C}$ ages of tufas (PL91-503g and PL91-604g) that enclose them (Table 2).

Benson and Thompson (1987), in a comparison of the ${ }^{14} \mathrm{C}$ ages of organic and inorganic carbonbearing materials, demonstrated that tufas could acquire secondary carbon in the subaerial environment. This study determined that addition of secondary carbon, via a dissolution-reprecipitation process, occurred in some relatively dense tufas after they were subaerially exposed. Therefore, the ${ }^{14} \mathrm{C}$ ages of many tufas that have been exposed to the subaerial environment are minimum limiting estimates of their time of formation.

Some evidence, however, indicates that some tufas have remained closed systems with respect to carbon transfer. Factors that seem to support the maintenance of a closed system, are sample thickness and burial of the sample under a thick layer of impermeable sediment. The thicker the sample, the more difficult it is for secondary material to reach the sample interior. For example, samples of very old (uranium-series ages of $270,000,185,000$ and 62,000 yr B.P., Table 4) thick, dense tufas that cement talus and coat the 


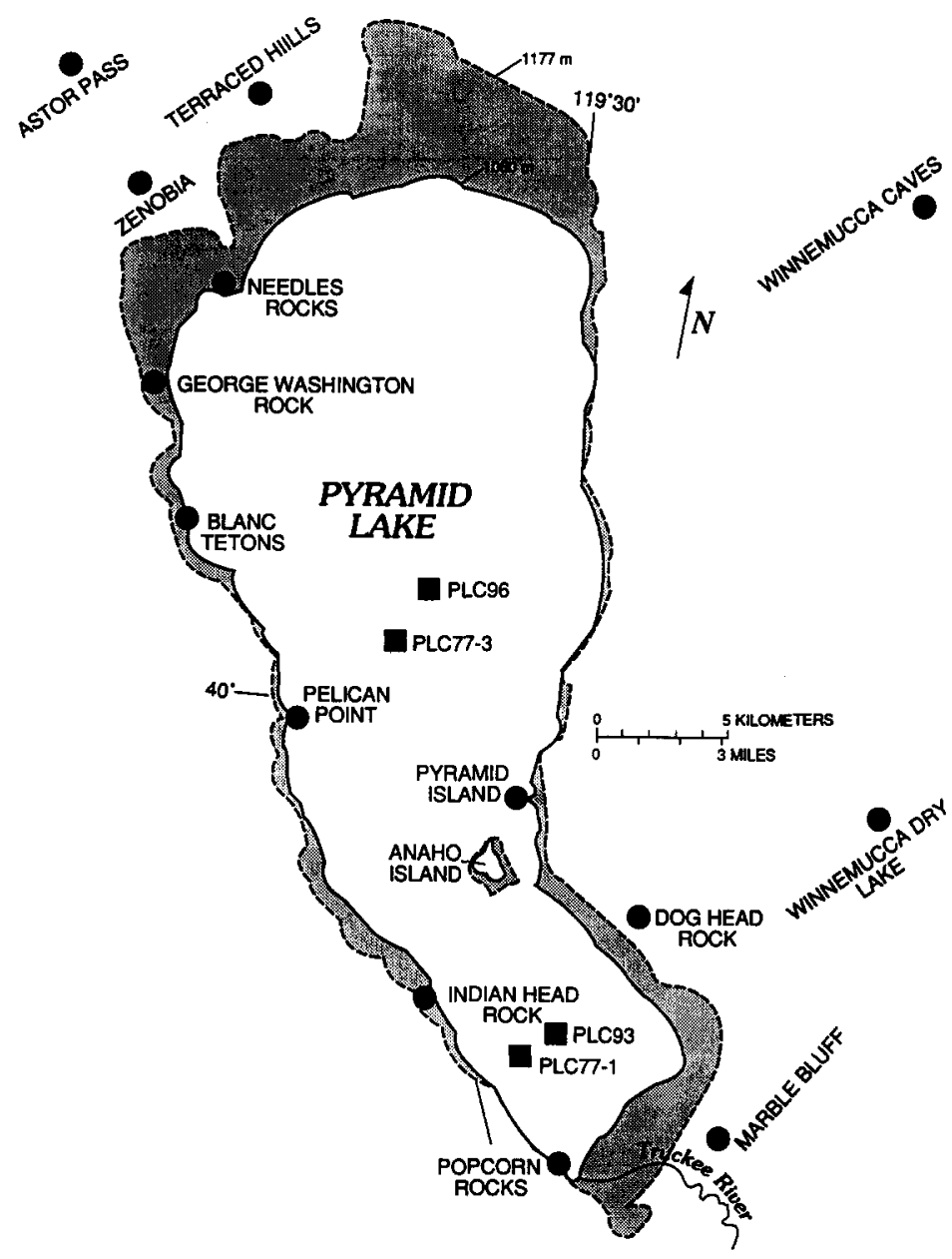

Fig. 2. Locations of tufa sampling sites (filled circles) and sediment-core sites (filled squares) in the Pyramid Lake and Winnemucca Lake subbasins.

surface of a small cave at the Marble Bluff site (see fig. 18 in Benson, 1994) have infinite radiocarbon ages $(>33,000,>41,000$ and $>50,000$ yr B.P., Table 4).

Consistency of tufa ages also indicates the maintenance of a closed system. Three highstand (1330 m) samples (WL101, 102 and 103) from the Walker Lake subbasin have identical ${ }^{14} \mathrm{C}$ ages $(13,810 \pm 210,13,760 \pm 210$ and $13,760 \pm 210 \mathrm{yr}$ B.P., Benson, 1993). Co-deposited samples of different mineralogy that yield the same age also indicate maintenance of a closed system. For example, dense calcite tufas and aragonite gastropods from two locations in the Pyramid Lake subbasin were shown to yield nearly identical ${ }^{14} \mathrm{C}$ ages (Benson, 1978).

Burial of tufa beneath a thick layer of sediment tends to protect the sample from contamination. The bases of many of tufa mounds (below an elevation of $1164 \mathrm{~m}$ ) at the Blanc Teton and Pelican Point sites were covered with sediment until 1986 and remained uncemented; e.g., the thinolite variety of tufa still consists of long porous crystals (see fig. 5 in Benson, 1994). Tufa mounds such as those at Needles Rocks (Fig. 2), however, have been exposed to lake water for several thousand years. The bases of these mounds (below an elevation of $1182 \mathrm{~m}$ ) are densely cemented with 
Table 3

Inorganic and isotopic chemistry of ground water in the Pyramid Lake system. Inorganic constituents reported in millimoles per liter; alkalinity reported as bicarbonate in millequivalents per liter; conductivity reported in millisiemens per centimeter; - $=$ absence of data; $\delta^{13} \mathrm{C}$ reported in parts per thousand (\%) relative to $\mathrm{PDB} ; \delta^{18} \mathrm{O}$ and $\delta^{2} \mathrm{H}$ reported in \%o relative to SMOW. Samples for isotopic analysis were taken in 1992 and 1993

\begin{tabular}{|c|c|c|c|c|c|c|}
\hline Site & $\begin{array}{l}\text { Needles } \\
\text { Well }\end{array}$ & $\begin{array}{l}\text { Needles } \\
\text { spring }\end{array}$ & $\begin{array}{l}\text { Popcorn } \\
\text { Rocks } \\
\text { spring }\end{array}$ & $\begin{array}{l}\text { Blanc } \\
\text { Tetons } \\
\text { spring }\end{array}$ & $\begin{array}{l}\text { Pelican } \\
\text { Point } \\
\text { spring }\end{array}$ & $\begin{array}{l}\text { Pyramid } \\
\text { Island } \\
\text { spring }\end{array}$ \\
\hline Date & $8 / 20 / 92$ & $8 / 20 / 92$ & $8 / 20 / 92$ & $8 / 7 / 93$ & 1977 & $10 / 7 / 91$ \\
\hline $\mathrm{pH}$ & 8.3 & 7.5 & 8.5 & 8.3 & 9.3 & - \\
\hline Cond. & 4.47 & 5.51 & 7.60 & 0.62 & 5.45 & - \\
\hline$T\left({ }^{\circ} \mathrm{C}\right)$ & 85.3 & 57.8 & 13.0 & 17.0 & 15.5 & 89.0 \\
\hline $\mathrm{Ca}$ & 5.7 & 4.3 & 0.21 & 0.043 & 0.081 & - \\
\hline $\mathrm{Mg}$ & 0.002 & 1.4 & 2.22 & 0.036 & 1.48 & - \\
\hline $\mathrm{Sr}$ & 0.057 & 0.046 & 0.0095 & 0.00025 & - & - \\
\hline $\mathrm{Ba}$ & 0.00080 & 0.00073 & 0.00080 & 0.00013 & - & - \\
\hline $\mathrm{Na}$ & 35.2 & 47.4 & 83.1 & 4.59 & 44.5 & - \\
\hline $\mathrm{K}$ & 0.62 & 1.19 & 1.11 & 0.029 & 1.5 & - \\
\hline $\mathrm{Li}$ & 0.085 & 0.11 & 0.012 & 0.0025 & - & - \\
\hline Alk. & 0.24 & 2.04 & 24.7 & 4.68 & 14.0 & - \\
\hline $\mathrm{Cl}$ & 52.4 & 62.7 & 73.6 & 1.09 & 32.4 & - \\
\hline $\mathrm{SO}_{4}$ & 3.49 & 3.84 & 5.48 & 0.268 & 1.82 & - \\
\hline $\mathrm{SiO}_{2}$ & 1.56 & 1.41 & 0.37 & 0.49 & 0.065 & - \\
\hline $\mathrm{B}$ & 0.42 & 0.52 & 0.62 & 0.035 & - & - \\
\hline$\delta^{13} \mathrm{C}$ & - & -3.2 & -8.2 & -9.9 & - & - \\
\hline$\delta^{18} \mathrm{O}$ & -11.6 & $\begin{array}{l}-12.2 \\
-12.3 \\
-12.0\end{array}$ & $\begin{array}{r}-9.0 \\
-9.4 \\
-10.8 \\
-9.2\end{array}$ & $\begin{array}{l}-14.6 \\
-14.8\end{array}$ & - & -9.60 \\
\hline$\delta^{2} \mathrm{H}$ & -106.0 & $\begin{array}{l}-107.5 \\
-104.0 \\
-105.5\end{array}$ & $\begin{array}{l}-83.5 \\
-81.0 \\
-88.5 \\
-84.5\end{array}$ & $\begin{array}{l}-113.0 \\
-112.8\end{array}$ & - & -91.0 \\
\hline
\end{tabular}

secondary carbonate (see figs. 9 and 13 in Benson, 1994).

Sample elevation also affects tufa preservation; i.e., the higher the elevation of a tufa sample, the less time it has spent under water. High-elevation tufas, therefore, have had less time to acquire multiple generations of carbonate cement from the subaqueous environment.

\subsection{Radiocarbon ages of carbon-bearing materials} from tufa mounds located near the present shore of Pyramid Lake

\section{Tubular tufas}

The insides and bases of all tufa mounds contain tubular structures. Broken tubular tufas consisting of concentric layers of dense laminated tufa ${ }^{1}$ are exposed at the Popcorn Rocks site (Fig. 2; see fig. 15 in Benson, 1994). Radiocarbon determinations on four laminae from one of these tubes yielded ages ranging from $41,380 \pm 1500$ to $37,220 \pm 860$ yr B.P. (samples PLPR92-2i, j, k and 1, Table 2). Ages of the three innermost samples (PLPR 92-2i, $\mathrm{j}$ and $\mathrm{k}$ ) are statistically identical and are $\sim 4000$ yr older than the age of the outermost layer (PLPR92-21). All four layers are relatively porous and have ages that are essentially infinite with respect to a ${ }^{14} \mathrm{C}$ determination. It is therefore difficult, if not impossible, to assess the reliability

\footnotetext{
${ }^{1}$ Tubes containing branching as well as densely laminated varieties of tufa.
} 


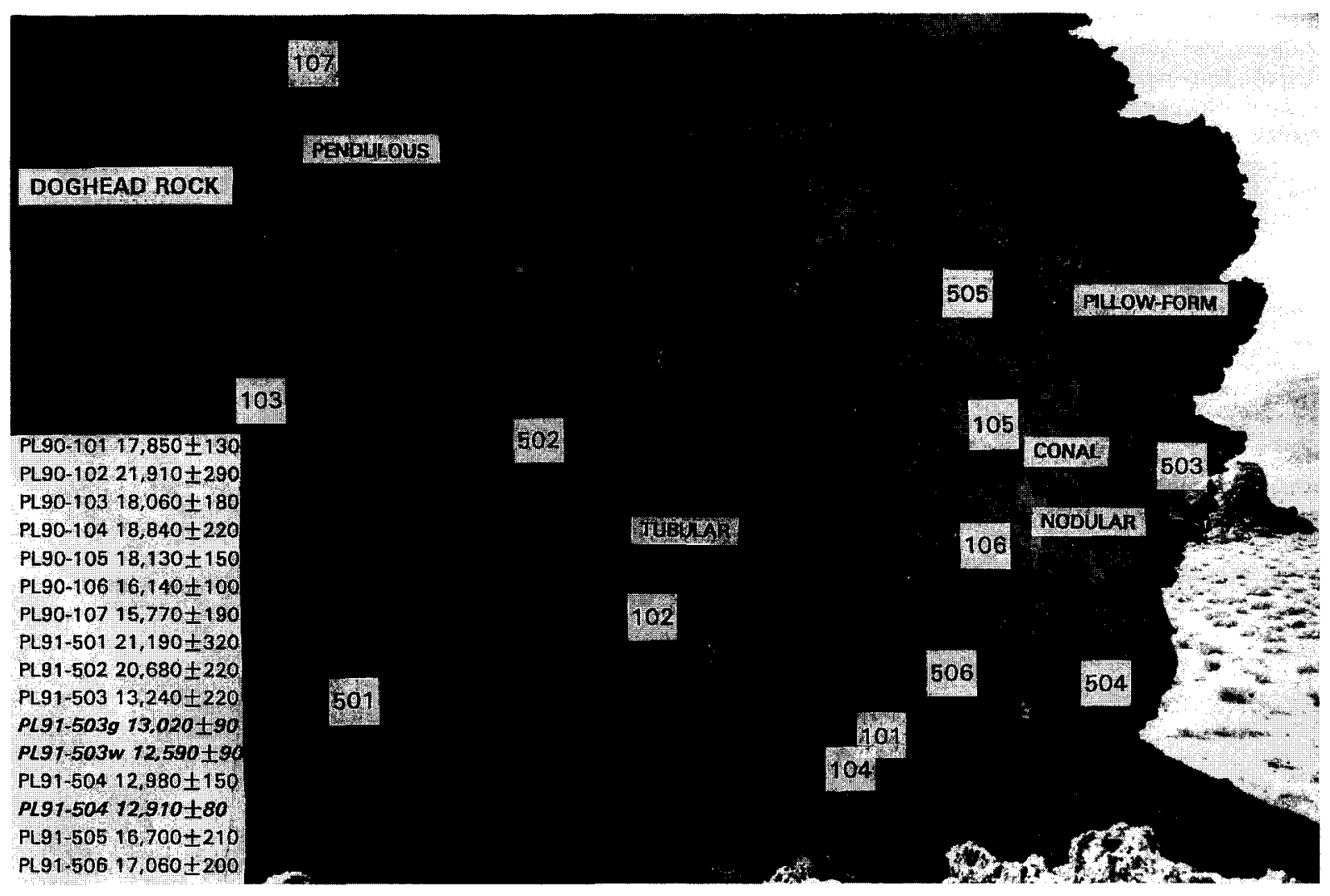

Fig. 3. Locations and radiocarbon ages of tufa samples from the Doghead Rock site. Elevation of base of outcrop is at $\sim 1215 \mathrm{~m}$. Exposed side of mound is $\sim 5 \mathrm{~m}$ high. Tubular tufas are exposed in the lower center of the mound. Pillow-form, conal and nodular tufas are exposed on right side of photograph. Pendulous tufa is visible in upper left of photograph. Sample number ending in a $w$ indicates white secondary carbonate cement.

of the ${ }^{14} \mathrm{C}$ ages, given the low activity of carbon remaining in the samples and the possiblity of incorporation of dead carbon during formation of the tube.

Large cylindrical tufas also are exposed at Pelican Point (Figs. 2 and 5, see fig. 26 in Benson, 1994). Two samples from the outer surface of one of the cylinders (PLPP92-9, Table 2) yielded ${ }^{14} \mathrm{C}$ ages of $34,340 \pm 1260$ and $31,580 \pm 530 \mathrm{yr}$ B.P. Two small tubular tufas from the Needles Rocks site (Fig. 2) also were dated. Samples of PL90-116 ${ }^{1}$ yielded statistically indistinguishable ${ }^{14} \mathrm{C}$ ages of $32,410 \pm 560$ and $31,640 \pm 640$ yr B.P., and samples of PL90-114 yielded similar ${ }^{14} \mathrm{C}$ ages of $30,880 \pm 470$ and $29,720 \pm 590$ yr B.P. (Table 2).

\footnotetext{
${ }^{1}$ Sample PL90-116 came from the base of a hive-shaped broken tufa mound that had fallen from an elevation $>1190 \mathrm{~m}$.
}

The ${ }^{14} \mathrm{C}$ ages of low elevation $(<1207 \mathrm{~m})$ tubular tufas indicate that they formed between $\sim 35,000$ and $\sim 30,000 \mathrm{yr}$ B.P. However, the shapes of the tubular tufas imply that the tubes were conduits for ground-water discharge to Pyramid Lake. Because the tubes may have formed from a mixture of lake and ground water, their ${ }^{14} \mathrm{C}$ ages should be considered maximum estimates of the time of their formation.

\section{Old branching tufas}

The Pelican Point site contains the best exposure of old branching tufas (Fig. 5, see figs. 12 and 26 in Benson, 1994). Radiocarbon ages of old branching tufa at this site ranged from $35,170 \pm 850$ to $19,150 \pm 120 \mathrm{yr}$ B.P. (Fig. 5, Table 2). The ages of carbonate casts (PLPP92-5t and PLPP92-6t) 


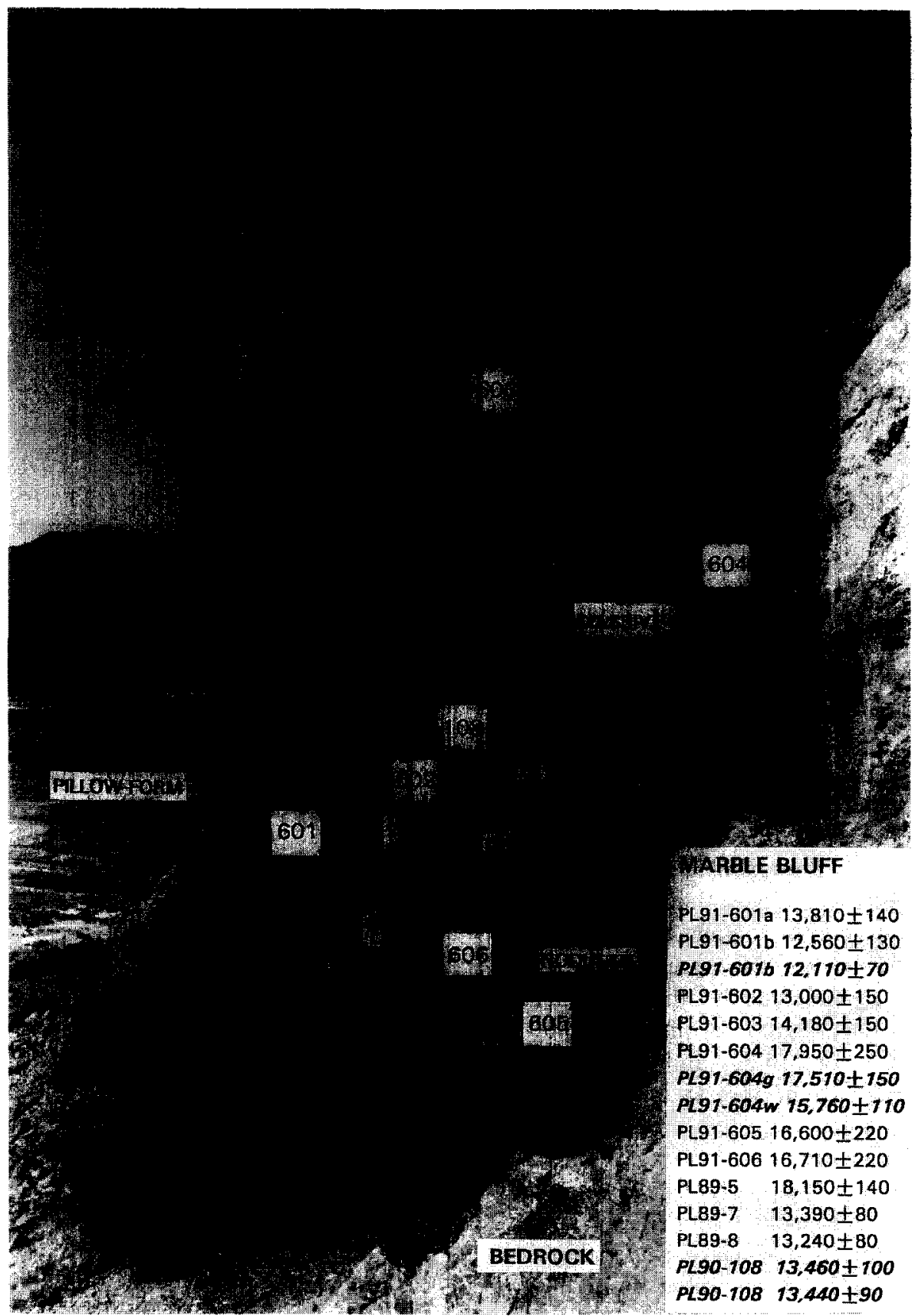

Fig. 4. Locations and radiocarbon ages of tufa samples from the Marble Bluff site. Elevation of base of outcrop is at $\sim 1250 \mathrm{~m}$. Carbonate body is $2-\mathrm{m}$ wide. Inner $1 \mathrm{~m}$ of carbonate next to bedrock consists of massive carbonate with pockets of nodular tufa. Outer $1 \mathrm{~m}$ of carbonate contains overlapping pillow-form tufas that contain nodular and conal tufas. Sample numbers ending in a $w$ indicate white secondary carbonate cement. 
Table 4

Elevations, uranium concentrations, isotopic activity ratios and estimated uranium-series ages of dense tufa cementing talus and lining cave at Marble Bluff site in the Pyramid Lake subbasin. Letters in parentheses after sample number indicate analyst (YL= Yong Lao of Lamont-Doherty Geological Observatory and JB= James Bischoff of the U.S. Geological Survey). Slopes of ${ }^{230} \mathrm{Th} /{ }^{232} \mathrm{Th}$ versus ${ }^{234} \mathrm{U} /{ }^{232} \mathrm{Th}$ and ${ }^{234} \mathrm{U} /{ }^{232} \mathrm{Th}$ versus ${ }^{238} \mathrm{U} /{ }^{232} \mathrm{Th}$ plots of six subsamples, three each from PL88-1 and PL88-2, were used to calculate the ${ }^{230} \mathrm{Th} /{ }^{234} \mathrm{U}$ and ${ }^{234} \mathrm{U} /{ }^{238} \mathrm{U}$ ratios using the YORK-FIT program (York, 1979)

\begin{tabular}{|c|c|c|c|c|c|c|}
\hline $\begin{array}{l}\text { Sample } \\
\text { number }\end{array}$ & $\begin{array}{l}\text { Elevation } \\
\text { (m) }\end{array}$ & $\begin{array}{l}{ }^{238} \mathrm{U} \\
(\mathrm{ppm})\end{array}$ & $\begin{array}{l}{ }^{234} \mathrm{U} /{ }^{238} \mathrm{U} \quad{ }^{230} \mathrm{Th} /{ }^{234} \mathrm{U} \\
\text { (Activity ratios) }\end{array}$ & ${ }^{230} \mathrm{Th} /{ }^{232} \mathrm{Th}$ & $\begin{array}{l}\text { U-series age } \\
\left(10^{3} \mathrm{yr} \text { B.P. }\right)\end{array}$ & $\begin{array}{l}{ }^{14} \mathrm{C} \text { age } \\
\left(10^{3} \text { yr B.P.) }\right.\end{array}$ \\
\hline \multicolumn{7}{|c|}{ Tufa cementing talus } \\
\hline PL88-1 (YL) & 1212 & $1.81 \pm 0.07$ & $1.553 \pm 0.0220 .446 \pm 0.012$ & - & $61.8 \pm 2.3$ & $33.2 \pm 1.7$ \\
\hline PL88-2 (YL) & & $2.47 \pm 0.09$ & & & & \\
\hline PL89-19 (YL) & 1209 & $5.29 \pm 0.10$ & $1.350 \pm 0.0130 .869 \pm 0.020$ & $19.59 \pm 0.51$ & $187.1 \pm 11.0$ & $>50$ \\
\hline PL89-19 (JB) & 1209 & $7.75 \pm 0.12$ & $1.380 \pm 0.010 \quad 0.870 \pm 0.020$ & $49.68 \pm 2.14$ & $183.5 \pm 8.9$ & \\
\hline PL89-21 (JB) & 1206 & $2.12 \pm 0.04$ & $1.210 \pm 0.0200 .960 \pm 0.020$ & $36.75 \pm 2.78$ & $269.0 \pm 29.1$ & \\
\hline \multicolumn{7}{|l|}{ Tufa lining cave } \\
\hline PL89-20a (YL) & 1204 & $2.11 \pm 0.04$ & $1.270 \pm 0.020 \quad 0.855 \pm 0.021$ & $10.85 \pm 0.32$ & $184.2 \pm 12.1$ & $>41$ \\
\hline
\end{tabular}

found cemented to two mounds ${ }^{1}$ are stratigraphically consistent with, but much younger than, the ages of roots (PLPP92-5w and PLPP92-6w) they enclose (Fig. 5). The gap in time between the root and cast ages $(\sim 4000-10,000$ yr, Fig. 5) seems inordinately long. It is difficult to envision how dead roots could remain intact and uncoated for such long times unless they were covered and preserved by anoxic lake sediment for up to 10,000 yr. The possiblity also exists that the carbonate casts have been contaminated with secondary (modern) carbon. Given the uncertainties in the ages, we tentatively conclude that the old branching tufas may also have begun forming $\sim 35,000 \mathrm{yr}$ B.P. The coevality of tubular and old branching tufas is consistent with the observation that tubular tufas contain layers of old branching tufa (Benson, 1994a).

The ${ }^{14} \mathrm{C}$ ages of two samples of old branching tufa (PLPR92-1), deposited immediately before precipitation of the first layer of young thinolitic tufa at the Popcorn Rock site, differ by $\sim 2300 \mathrm{yr}$. The oldest of the ${ }^{14} \mathrm{C}$ dates $(19,630 \pm 140 \mathrm{yr}$ B.P.) is similar to ${ }^{14} \mathrm{C}$ dates $(20,770 \pm 170$ to $19,150 \pm 120$ yr B.P.) obtained on samples (PLPP92-1, PLPP92-2, and PLPP92-7) collected from the same tufa layer at Pelican Point. Because samples from

\footnotetext{
${ }^{1}$ Samples PLPP92-5t and 6t came from the outer surfaces of different mounds.
}

Popcorn Rock are coated with white secondary carbonate, their ages represent minimum estimates of the time of final deposition of old branching tufa. The youngest ${ }^{14} \mathrm{C}$ age of the Pelican Point old branching tufas is, therefore, rejected and we conclude that old branching tufas continued to form until $\sim 19,000 \mathrm{yr}$ B.P.

\section{Tufas deposited since formation of old branching tufas}

Most of the tufa varieties deposited after formation of old branching tufa are exposed at the Blanc Tetons site (Figs. 6 and 7). The lowermost layer of young thinolitic tufa (PL90-109a, Table 2) at this site has a ${ }^{14} \mathrm{C}$ age of $20,150 \pm 160$ yr B.P. This date is consistent with the age $(20,770 \pm 170 \mathrm{yr}$ B.P.) of a sample (PLPP92-2, Table 2) of the same variety of tufa taken from Pelican Point. Shearman et al. (1989) consider that ikaite, the hexahydrate of calcium carbonate, was the precursor of thinolitic tufas. The formation of ikaite indicates the presence of very cold water. In addition, high levels of dissolved orthophosphate seem necessary to prevent rapid conversion of ikaite to a more thermodynamically stable form of carbonate (Bischoff et al., 1993). Ikaite has often been found forming near the outlets of calcium-rich bicarbonate-bearing springs (Pauly, 1963; Bischoff et al., 1993 ) indicating that it may incorporate dead 




Fig. 5. Schematic sequence of tufa deposition at the Pelican Point site, showing radiocarbon ages of some tufa types. Tufa complexes at this site are typically $2-3 \mathrm{~m}$ in height. 


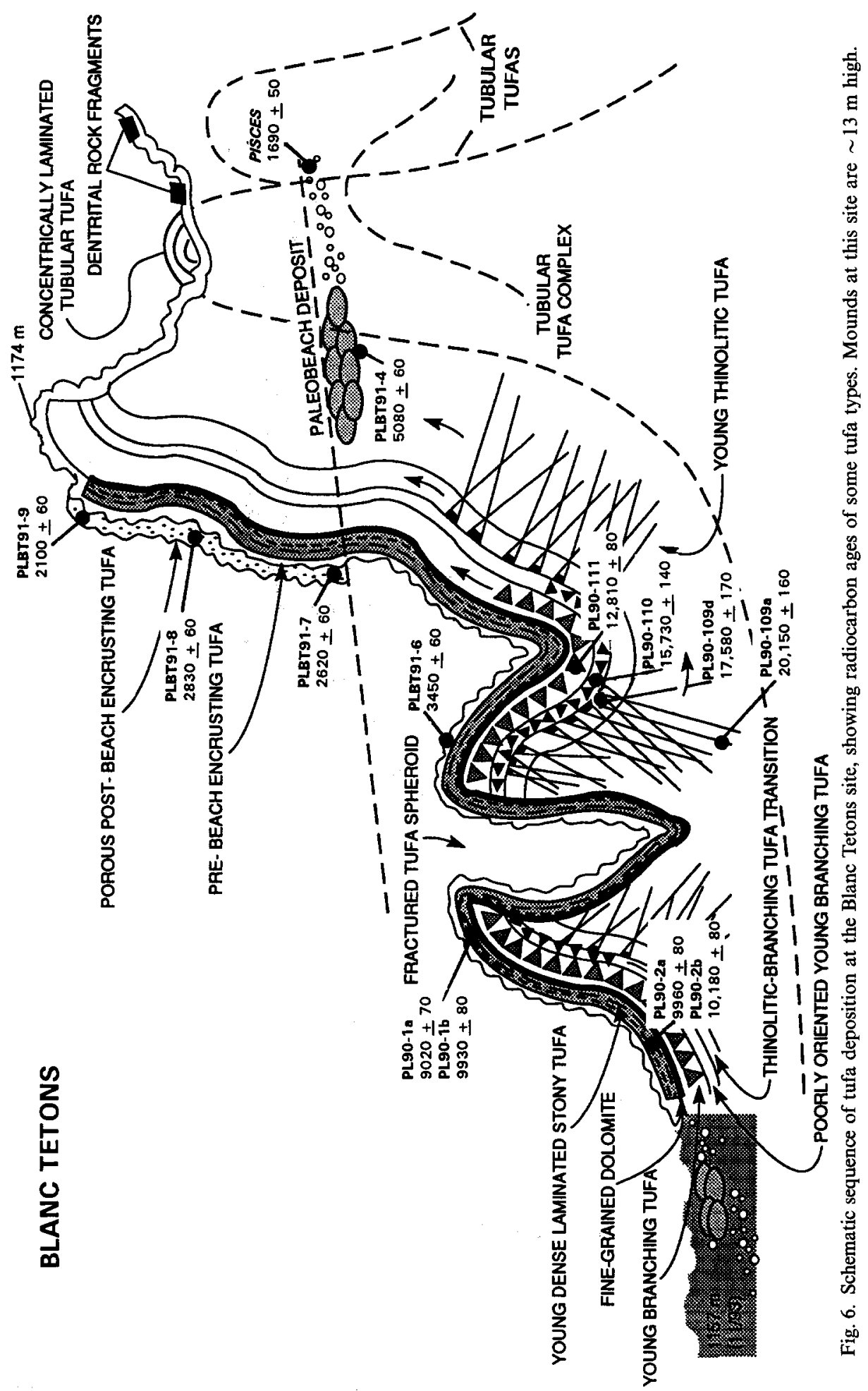




\section{BLANC TETONS}
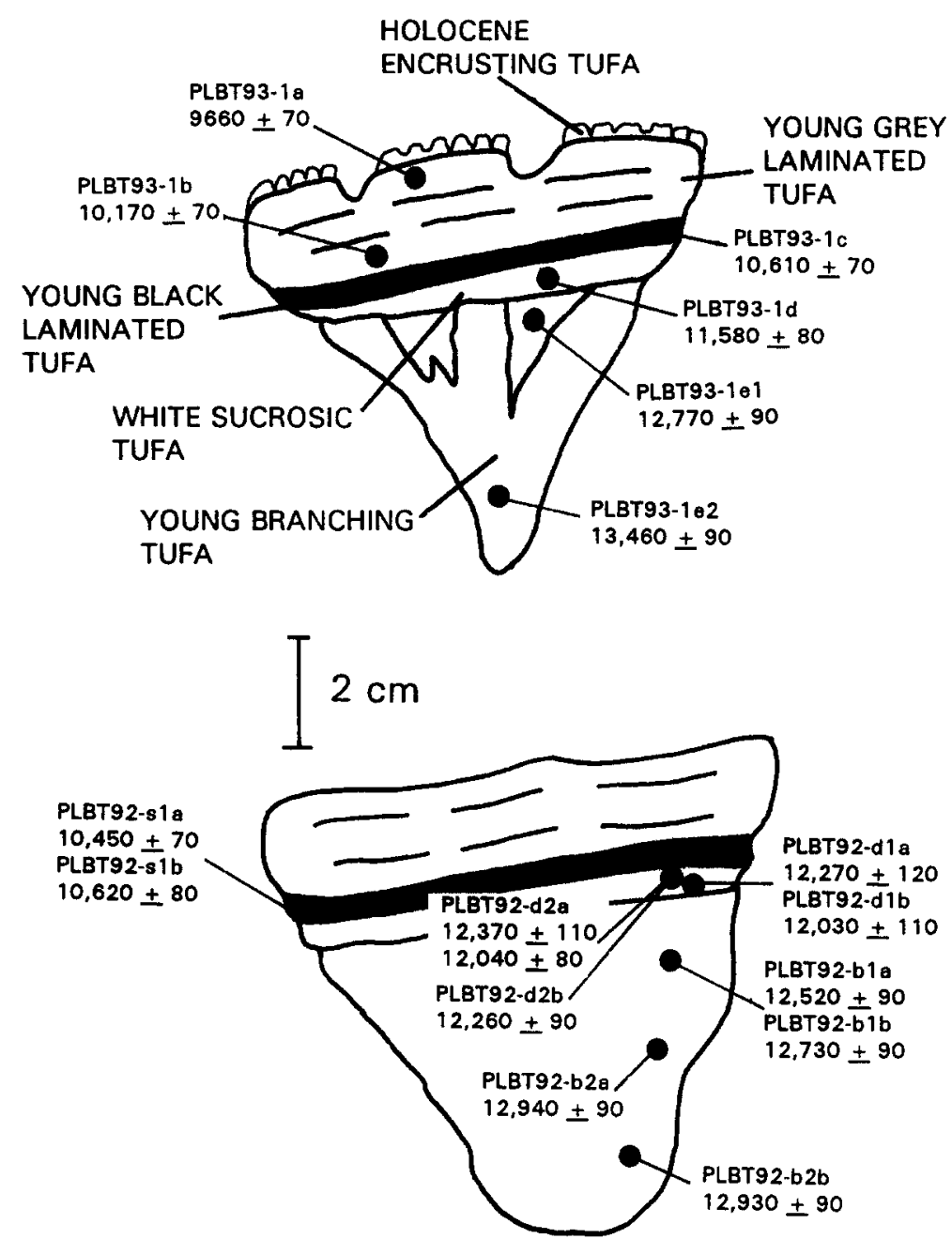

Fig. 7. Radiocarbon ages of young branching tufa, white sucrosic (dolomitic) tufa, and young laminated tufa from the Blanc Tetons site. The laminated tufa averages $\sim 2 \mathrm{~cm}$ in thickness.

carbon as it forms. However, the ages of PL90-109a and PLPP92-2 are essentially the same as the ages of the last generation of old branching tufa coated by the thinolite. The similarity of ages is unexpected since it was thought that ikaite/ thinolite would persist as the metastable hexahydrate for a lengthy period of time prior to recrystallization to a more stable carbonate. For example,
Broecker and Kaufman (1965) found that thinolite contained within a tufa dome from the Needles Rocks site dated $\sim 4000$ yr younger than the branching tufa that surrounded it. It seems, however, that the thinolitic tufas at the Blanc Tetons recrystallized soon after formation. Thinolites in the bases of tufa mounds at Needles Rocks are densely cemented with secondary carbonate. 
Therefore, the ${ }^{14} \mathrm{C}$ age of the Needles Rocks thinolites dated by Broecker and Kaufman (1965) probably represents the introduction of secondary carbonate cement that filled the porous thinolite framework.

The transition from young thinolite to young branching tufa (PL90-109d) at the Blanc Tetons site has a ${ }^{14} \mathrm{C}$ age of $17,580 \pm 170$ yr B.P. (Table 2, see fig. 31 in Benson, 1994). Young branching tufas at this site range in age from $15,730 \pm 140$ to $12,590 \pm 90$ yr B.P. (Table 2). Because thinolitic (ikaite) tufas are expected to have formed in very cold water, Benson (1994a) hypothesized that the young thinolites formed in the hypolimnetic waters of Lake Lahontan. The period of thinolite formation, therefore, indicates that Lake Lahontan was deep between $\sim 21,000$ and $\sim 17,600$ yr B.P.

After deposition of the last generation of young branching tufa at the Blanc Tetons site, the base of the mound was exposed by a drop in lake level accompanied by the erosion of lake sediment that previously covered the flanks of the mound. When the supporting sediment was removed, some large tufa spheroids on the flanks of the mound cracked open (see Fig. 5 in Benson, 1994a) and were subsequently coated with a $0.5-\mathrm{cm}$ thick layer of sucrosic tufa (dolomite). The ${ }^{14} \mathrm{C}$ age of the dolomite ranges from $12,370 \pm 110$ to $11,580 \pm 80$ yr B.P. (Fig. 7, Table 2). The dolomite is porous, and $\mathrm{x}$-ray diffraction studies of sample PLBT93-1d indicate that this sample also contains calcite. Petrographic studies indicate that the calcite was added after the dolomite formed. If we reject the age of this sample contaminated with secondary carbon, the remaining data indicate that dolomite precipitation occurred between 12,400 and 12,000 yr B.P. Because dolomite precipitation has been shown to occur in saline, alkaline lakes having a high magnesium to calcium ratio (De Deckker and Last, 1988), we infer that Lake Lahontan was at low levels $(\sim 1260 \mathrm{~m})$ between 12,400 and $12,000 \mathrm{yr}$ ago.

The age of a $2-\mathrm{cm}$ thick young dense laminated tufa that overlies the dolomite at the Blanc Tetons site ranges in age from $10,960 \pm 80$ to $9020 \pm 70 \mathrm{yr}$ B.P. (Fig. 7, Table 2). Dates on this tufa at the Winnemucca Lake and Pyramid Island sites (Fig. 2 , Table 2) also fall within the 11,000-9000 yr age range. The gap in tufa formation between 12,000 and 11,000 yr B.P. indicates the possibility that Lake Lahontan fell below $1259 \mathrm{~m}$ during this time. The young dense laminated tufa occurs between 1159 and $1205 \mathrm{~m}$, indicating that Lake Lahontan rose after 11,000 yr B.P. reaching the spill point to the Smoke Creek-Black Rock Desert subbasin prior to $9000 \mathrm{yr}$ B.P.

A thin porous tufa that encrusts carbonate cemented cobbles (see Figs. 7 and 33 in Benson, 1994) perched on the side of the Blanc Tetons mound at $1166 \mathrm{~m}$ (Fig. 6 ) has a ${ }^{14} \mathrm{C}$ age of $5080 \pm 60$ yr B.P. (PLBT91-4, Table 2). Thicker encrusting tufas from higher elevations $(1167-1175 \mathrm{~m})$ on the mound range in age from $3450 \pm 60$ to $2100 \pm 60 \mathrm{yr}$ B.P. (Fig. 6, Table 2). X-ray diffraction studies of samples of the encrusting tufa indicate that it is usually composed of aragonite and sometimes contains small amounts of dolomite, minerals that probably precipitated from relatively saline lake water. The mineralogic and elevational data indicate that Pyramid Lake was at or below the spill point to the Winnemucca Lake subbasin for most of the middle and late Holocene.

\section{Beachrock deposits}

A sandy beach deposit, containing fossil fish bones, occurs at an elevation of $\sim 1167 \mathrm{~m}$ on the north side of the southern Blanc Tetons mound. The ${ }^{14} \mathrm{C}$ age of purified collagen extracted from the fish bones (CAMS-5892) is $1690 \pm 50$ yr B.P. Beachrock also occurs at many other sites bordering Pyramid Lake between elevations of 1170 and $1182 \mathrm{~m}$ (see fig. 16 in Benson, 1994). Dates on samples from these deposits range from $3590 \pm 90$ to $1350 \pm 70 \mathrm{yr}$ B.P. (Table 2). This age range is similar to ages of beach deposits and encrusting shallow-water tufas found at the Blanc Tetons site supporting our conclusion that Pyramid Lake was at or below the spill point to the Winnemucca Lake subbasin for most of the middle and lake Holocene.

\subsection{Radiocarbon ages of carbon-bearing materials from tufa mounds located above $1207 \mathrm{~m}$}

Tufa sequences from higher elevations are generally not as complete as those from low elevations, but they do provide information on the timing and maximum vertical extent of tufa occurrence. 


\section{Dog Head Rock}

The base of the eastern side of Dog Head Rock (Fig. 2) lies at an elevation of $\sim 1215 \mathrm{~m}$. At this location, the side of a hive shaped tufa mound has collapsed, exposing the central core of the mound (Fig. 3). Tubular tufas (3-5 $\mathrm{cm}$ in diameter) are exposed at the base of the hive shaped mound (Fig. 3, see fig. 14 in Benson, 1994). The tubes range in age from $21,910 \pm 290$ to $18,060 \pm 180 \mathrm{yr}$ B.P. (Table 2). Because we associate tube formation with ground-water discharge, the age of the tubes are considered maximum estimates of the times of formation. The ages of these tubes are much younger than the ages of tubes contained in mounds located along Pyramid Lake's periphery, indicating that lake level had not reached $1215 \mathrm{~m}$ until $\sim 21,900$ yr B.P.

Young branching tufa at Dog Head Rock includes stony, nodular, mammillary, and conal shapes that form drape and pillow structures (Benson, 1994). The ${ }^{14} \mathrm{C}$ ages of these tufas range from $18,840 \pm 220$ to $12,910 \pm 80$ yr B.P. (Fig. 3, Table 2) with tufa age decreasing towards the outer edge of the hive structure. The age data for tubular and young branching tufa imply that lake level remained above $1215 \mathrm{~m}$ between $\sim 22,000$ and $\sim 12,900$ yr B.P.

\section{Marble Bluff}

A reef-form tufa at $1251 \mathrm{~m}$ at the Marble Bluff site (Fig. 2) also contains young branching tufas with stony, nodular, mammillary, and conal shapes (Fig. 4). The ages of uncontaminated samples from this site range from $18,150 \pm 140$ to $12,560 \pm 130$ yr B.P. (Table 2). Two tufas from pillows at a lower elevation $(1234 \mathrm{~m})$ at Marble Bluff have ${ }^{14} \mathrm{C}$ ages of $18,880 \pm 240$ and $17,110 \pm 190$ yr B.P. (Table 2). The age range of these young branching tufas indicates that lake level remained above $1250 \mathrm{~m}$ between $\sim 18,200$ and $\sim 12,600$ yr B.P.

\section{Sequence of formation of tufa varieties and forms}

The age data presented above, together with the ages of chara deposits, gastropods embedded in the chara deposits and highstand dense coatings
(Table 2), allow us to determine the sequence of formation of tufa varieties (Fig. 8). Tufa sequences have been graphed for four elevational ranges: $<1182 \mathrm{~m}, 1182-1207 \mathrm{~m}, 1207-1265 \mathrm{~m}$, and $>1308$ $\mathrm{m}$. These ranges bear some relation to the hydrologic state of the the Lahontan system. When the lake surface was located below $1182 \mathrm{~m}$, Pyramid Lake was hydrologically isolated from other subbasins. When the lake surface was located between 1182 and $1207 \mathrm{~m}$, Pyramid and Winnemucca Lakes were joined. When the lake surface was located between 1207 and $1265 \mathrm{~m}$, lakes in the Pyramid, Winnemucca and Smoke Creek-Black Rock Desert subbasins were joined. If the Humboldt River discharged to the Black Rock Desert, Carson Lake received spill from the western Lahontan lakes when they rose to 1265 m. If, however, the Humboldt River discharged to the Carson Desert subbasin, Carson Lake joined with the western Lahontan lakes when lake levels were at $1265 \mathrm{~m}$. When lake surface exceeded 1308 $\mathrm{m}$, lakes in all seven Lahontan subbasins coalesced (see Table 5).

The data of Fig. 8 indicate the following: (1) the lower the elevation, the greater the time over which carbonate deposition has occurred, (2) tubular tufas formed at various elevations in the Pyramid Lake subbasin, implying that the groundwater potentiometric surface was much higher in the past, (3) old branching tufas (and tubular tufas that contain old branching tufa) that formed at low elevations were succeeded by young thinolitic tufas, (4) young thinolitic tufas formed at relatively low elevations $(<1220 \mathrm{~m})$ at the same time that young branching tufa and chara were deposited at higher elevations, (5) dolomitic tufas precipitated from between 12,400 and $12,000 \mathrm{yr}$ B.P. and aragonitic and dolomitic encrusting tufas precipitated in the latter part of the Holocene $(<3450 \mathrm{yr}$ B.P.), and (6) laminated fresh-water lowmagnesium-calcite tufas formed between 11,000 and 9000 yr B.P.

\section{The Lahontan lake-level record}

A lake-level synthesis based on the data of Table 2 is shown in Fig. 9. The lake-level record prior 


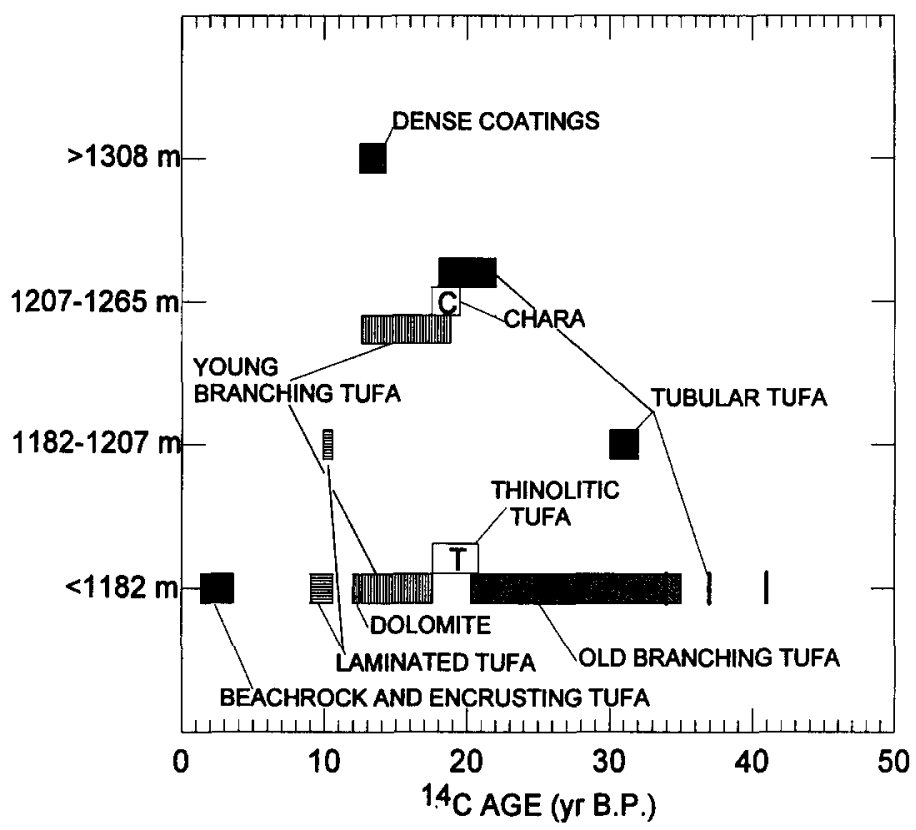

Fig. 8. Order of formation (paragenesis) of tufas in the Pyramid Lake and Winnemucca Lake subbasins shown for different elevations. Below $1182 \mathrm{~m}$, Pyramid Lake is confined to the Pyramid Lake subbasin. When Pyramid Lake reaches $1183 \mathrm{~m}$ (Mud Lake Slough Sill), it spills to the Winnemucca Lake subbasin. Above $1207 \mathrm{~m}$, the lake in the Pyramid and Winnemucca Lake subbasins spills to the Smoke Creek-Black Rock Desert subbasin across Emerson Pass Sill. When the lakes in the western Lahontan subbasins reach $1265 \mathrm{~m}$, spill occurs across the Darwin Pass Sill to the Carson Desert subbasin. Above $1308 \mathrm{~m}$, a single highstand lake occupies the seven Lahontan subbasins.

to $24,000 \mathrm{yr}$ B.P. cannot be accurately determined from the ${ }^{14} \mathrm{C}$ ages of tubular and old branching tufas that formed at low elevations in association with ground-water discharge. For this reason, these tufa ages have not been included in the lake-level synthesis. The lake-level envelope between 24,000 and 1500 yr B.P. was drawn above all water-laid deposits and below all subaerial deposits. Dates on organic materials deposited between 13,000 and $9000 \mathrm{yr}$ B.P. were taken from compilations in Thompson et al. (1986) and Benson et al. (1992).

\section{1. $27,500-15,500$ yr B.P.}

The most reliable data on lake level during this period comes from ${ }^{14} \mathrm{C}$ ages of amino acids extracted from the bones of a camel skeleton (Stafford et al., 1991). Dansie et al. (1990) have presented convincing arguments supporting a shallow-water death of the camel. Stafford (pers. comm.) believes that the best estimate of the ${ }^{14} \mathrm{C}$ age of the camel is $25,870 \pm 590 \mathrm{yr}$ B.P. (AA-2663) based on the XAD-purified hydrolysate fraction extracted in weak HCL. However, the age could be as young as $23,250 \pm 360$ yr B.P. (AA-2984) based on the ${ }^{14} \mathrm{C}$ age of the hydroxyproline fraction which is endemic to bone material. The ${ }^{14} \mathrm{C}$ ages of the youngest root cast found at Pelican Point (PLPP92-6T, Fig. 5) are statistically indistinguishable from the oldest age estimate for the camel. In addition, sample PLPPB92-1 (tufa filling the eye socket of a prehistoric horse) from Pelican Point has an ${ }^{14} \mathrm{C}$ age $(\sim 27,500$ yr B.P., Fig. 5) slightly older than the oldest age estimate for the camel. These data indicate that Pyramid Lake was at a low elevation $(\sim 1165 \mathrm{~m})$ at least part of the time between $\sim 27,500$ and $\sim 23,250$ yr B.P. (Fig. 9). By $\sim 21,000$ yr B.P, Lake Lahontan had reached the elevation of the $1265-\mathrm{m}$ sill at Darwin Pass.

The surface of Lake Lahontan seems to have remained near the elevation $(1165 \mathrm{~m})$ of the Darwin Pass spill point between $\sim 20,000$ and 
Table 5

Change in effective wetness associated with hydrologic states experienced by the Lahontan basin in the late Quaternary. For the purposes of this table, effective wetness is defined as the ratio of streamflow discharge associated with a hydrologic state relative to mean historical streamflow discharge. Streamflow data from Table 1 together with an evaporation rate of $1.25 \mathrm{~m} \mathrm{yr}^{-1}$ and surface areas listed in Table 2 were used in the calculation of effective wetness

Hydrologic state

Effective wetness

Humboldt River discharges to Carson Desert subbasin; Walker River discharges to Walker Lake subbasin Pyramid Lake reaches $1177 \mathrm{~m}$ and spills to Winnemucca Lake subbasin

Pyramid and Winnemucca Lakes coalesce at $1177 \mathrm{~m}$

1.42

Lake in Pyramid and Winnemucca Lake subbasins reaches $1207 \mathrm{~m}$ and spills to Smoke Creek-Black

Rock Desert subbasin

Walker Lake reaches $1308 \mathrm{~m}$ and spills to Carson Desert subbasin

Carson Lake reaches $1265 \mathrm{~m}$ and spills to lake in Pyramid and Winnemucca Lake subbasins; lake in

4.66

Pyramid and Winnemucca Lake subbasins continues to spill to Smoke Creek-Black Rock Desert subbasin and Walker Lake continues to spill to Carson Desert subbasin

Lakes in Pyramid, Winnemucca and Smoke Creek-Black Rock Desert subbasins coalesce at $1207 \mathrm{~m}$;

Walker Lake continues to spill to Carson Desert subbasin and Carson Lake continues to spill to

Pyramid Lake subbasin

Lake in Pyramid Lake, Winnemucca Lake and Smoke Creek-Black Rock Desert subbasins reaches

$1222 \mathrm{~m}$ and spills to Honey Lake subbasin; Walker Lake continues to spill to Carson Desert subbasin and Carson Lake continues to spill to Pyramid Lake subbasin

Lakes in Pyramid Lake, Winnemucca Lake, Smoke Creek-Black Rock Desert and Honey Lake subbasins coalesce at $1222 \mathrm{~m}$; Walker Lake continues to spill to Carson Desert subbasin and Carson Lake continues to spill to Pyramid Lake subbasin

Lake in Pyramid Lake, Winnemucca Lake, Smoke Creek-Black Rock Desert and Honey Lake subbasin reaches $1225 \mathrm{~m}$; Walker Lake continues to spill to Carson Desert subbasin and Carson Lake continues to spill to Pyramid Lake subbasin

Lakes in Pyramid Lake, Winnemucca Lake, Smoke Creek-Black Rock Desert, Honey Lake, Carson

Desert, and Buena Vista subbasins coalesce at $1265 \mathrm{~m}$; Walker Lake continues to spill to Carson

Desert subbasin

All lakes in Lahontan subbasins coalesce at $1308 \mathrm{~m}$

Lake Lahontan achieves $1335-\mathrm{m}$ highstand

Humboldt River discharges to Smoke Creek-Black Rock Desert subbasin; Walker River discharges to Walker Lake subbasin

Pyramid Lake reaches $1177 \mathrm{~m}$ and spills to Winnemucca Lake subbasin

Pyramid and Winnemucca Lakes coalesce at $1177 \mathrm{~m}$

Lake in Pyramid and Winnemucca Lake subbasins reaches $1207 \mathrm{~m}$ and spills to Smoke Creek-Black

Rock Desert subbasin

Lakes in Pyramid, Winnemucca and Smoke Creek-Black Rock Desert subbasins coalesce at $1207 \mathrm{~m}$

Walker Lake reaches $1208 \mathrm{~m}$ and spills to Carson Desert subbasin

Lake in Pyramid Lake, Winnemucca Lake and Smoke Creek-Black Rock Desert reaches $1222 \mathrm{~m}$ and

spills to Honey Lake subbasin; Walker Lake continues to spill to Carson Desert subbasin

Lakes in Pyramid Lake, Winnemucca Lake, Smoke Creek-Black Rock Desert and Honey Lake

subbasin coalesce at $1222 \mathrm{~m}$; Walker Lake continues to spill to Carson Desert subbasin

Lake in Pyramid Lake, Winnemucca Lake, Smoke Creek-Black Rock Desert and Honey Lake

subbasin reaches $1225 \mathrm{~m}$; Walker Lake continues to spill to Carson Desert subbasin

Lake in Pyramid Lake, Winnemucca Lake, Smoke Creek-Black Rock Desert and Honey Lake

subbasin reaches $1265 \mathrm{~m}$ and spills to Carson Desert subbasin; Walker Lake continues to spill to

Carson Desert subbasin

Lakes in Pyramid Lake, Winnemucca Lake, Smoke Creek-Black Rock Desert, Honey Lake, Carson

Desert and Buena Vista subbasins coalesce at $1265 \mathrm{~m}$; Walker Lake continues to spill to Carson

Desert subbasin

All lakes in Lahontan subbasins coalesce at $1308 \mathrm{~m}$

Lake Lahontan achieves $1335-\mathrm{m}$ highstand 
Table 5

Hydrologic state

Effective wetness

Humboldt River discharges to Carson Desert subbasin; Walker River discharges to Carson Desert subbasin Pyramid Lake reaches $1177 \mathrm{~m}$ and spills to Winnemucca Lake subbasin

0.98

1.42

1.75

Lake in Pyramid and Winnemucca Lake subbasins reaches $1207 \mathrm{~m}$ and spills to Smoke Creek-Black

Rock Desert subbasin

Carson Lake reaches $1265 \mathrm{~m}$ and spills to lake in Pyramid and Winnemucca Lake subbasins; lake in

Pyramid and Winnemucca Lake subbasins continues to spill to Smoke Creek-Black Rock Desert subbasins

Lakes in Pyramid, Winnemucca and Smoke Creek-Black Rock Desert subbasins coalesce at $1207 \mathrm{~m}$;

Carson Lake continues to spill to lake in Pyramid, Winnemucca, and Smoke Creek-Black Rock

Desert subbasins

Lake in Pyramid Lake, Winnemucca Lake, and Smoke Creek-Black Rock Desert reaches $1222 \mathrm{~m}$ and spills to Honey Lake subbasin; Carson Lake continues to spill to lake in Pyramid, Winnemucca, Honey Lake and Smoke Creek-Black Rock Desert subbasins

Lake in Pyramid Lake, Winnemucca Lake, Smoke Creek-Black Rock Desert and Honey Lake subbasin coalesce at $1222 \mathrm{~m}$; Carson Lake continues to spill to lake in Pyramid, Winnemucca, Honey Lake and Smoke Creek-Black Rock Desert subbasins

Lake in Pyramid, Winnemucca, Honey Lake and Smoke Creek-Black Rock Desert subbasins reach $1225 \mathrm{~m}$; Carson Lake continues to spill to lake in Pyramid, Winnemucca, Honey Lake and Smoke Creek-Black Rock Desert subbasins

Lake in Pyramid Lake, Winnemucca Lake, Smoke Creek-Black Rock Desert, Honey Lake, Carson Desert and Buena Vista subbasins coalesce at $1265 \mathrm{~m}$

Lake in Pyramid Lake, Winnemucca Lake, Smoke Creek-Black Rock Desert, Honey Lake, Carson

Desert and Buena Vista subbasins reaches $1308 \mathrm{~m}$ and spills to Walker Lake subbasin

All lakes in Lahontan basin coalesce at $1308 \mathrm{~m}$

Lake Lahontan achieves 1335 -m highstand

Humboldt River discharges to Smoke Creek-Black Rock Desert subbasin; Walker River discharges to Carson Desert subbasin

$\begin{array}{lr}\text { Pyramid Lake reaches } 1177 \mathrm{~m} \text { and spills to Winnemucca Lake subbasin } & 0.98\end{array}$

Pyramid and Winnemucca Lakes coalesce at $1177 \mathrm{~m}$

Lake in Pyramid and Winnemucca Lake subbasins reaches $1207 \mathrm{~m}$ and spills to Smoke Creek-Black

Rock Desert subbasin

Lakes in Pyramid, Winnemucca and Smoke Creek-Black Rock Desert subbasins coalesce at $1207 \mathrm{~m}$

Lake in Pyramid Lake, Winnemucca Lake, and Smoke Creek-Black Rock Desert reaches $1222 \mathrm{~m}$ and spills to Honey Lake subbasin

Lakes in Pyramid Lake, Winnemucca Lake, Smoke Creek-Black Rock Desert and Honey Lake subbasin coalesce at $1222 \mathrm{~m}$

Lake in Pyramid Lake, Winnemucca Lake, Smoke Creek-Black Rock Desert and Honey Lake subbasin reach $1225 \mathrm{~m}$

Lake in Pyramid Lake, Winnemucca Lake, Smoke Creek-Black Rock Desert and Honey Lake subbasin reaches $1265 \mathrm{~m}$ and spills to Carson Desert subbasin

Lakes in Pyramid Lake, Winnemucca Lake, Smoke Creek-Black Rock Desert, Honey Lake, Carson

Desert and Buena Vista subbasins coalesce at $1265 \mathrm{~m}$

Lake in Pyramid Lake, Winnemucca Lake, Smoke Creek-Black Rock Desert, Honey Lake and Carson Desert subbasins reaches $1308 \mathrm{~m}$ and spills to Walker Lake subbasin

All lakes in Lahontan basin coalesce at $1308 \mathrm{~m}$

$\sim 16,000$ yr B.P. (Fig. 9). Inaccuracies inherent in the ${ }^{14} \mathrm{C}$ data set and our inability to determine the absolute depth of formation of most of tufas make it impossible to draw a single line that depicts actual variations in lake level during this time interval. The occurrence of a soil intercalated in 


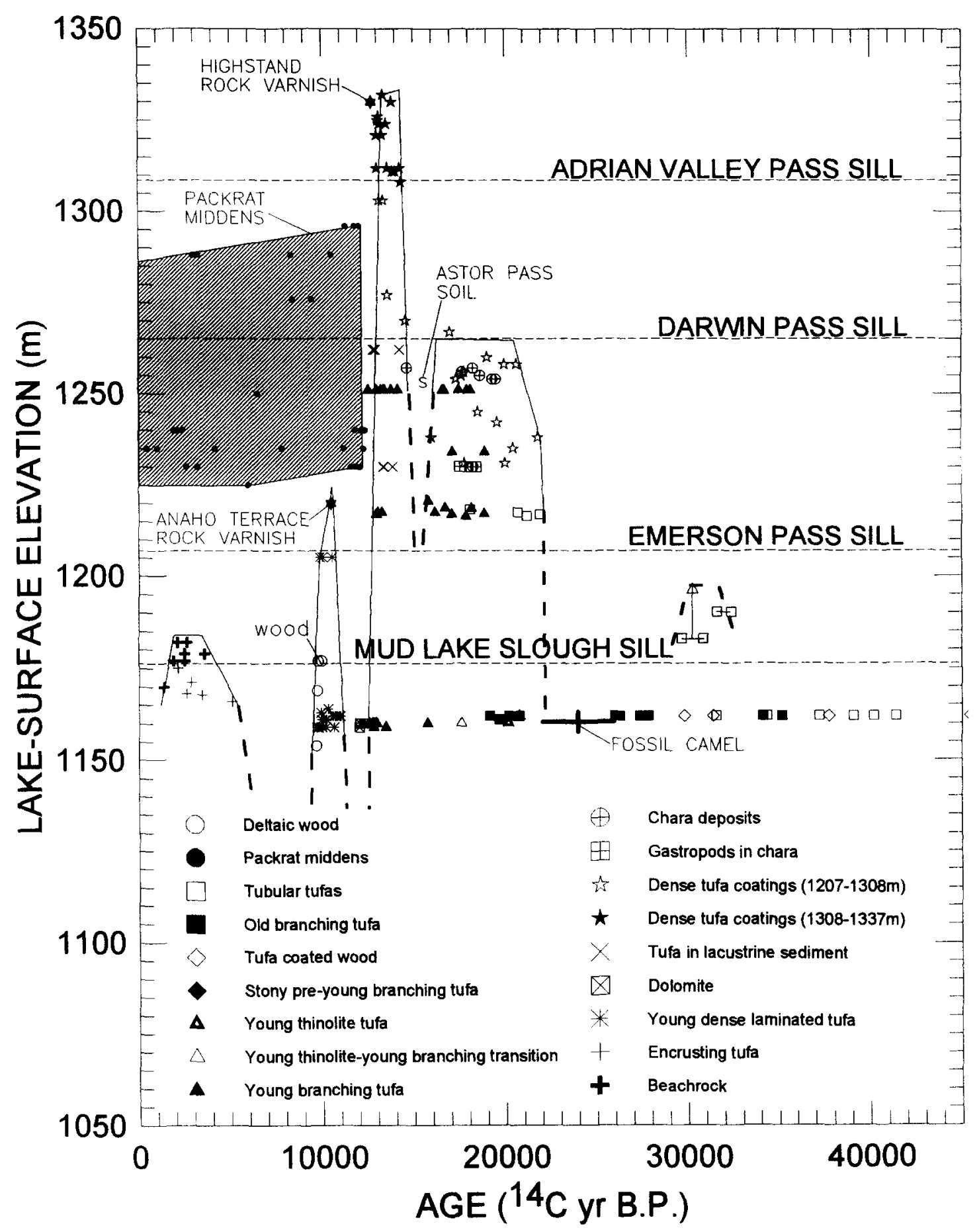

Fig. 9. Lahontan lake-level record for the past 35,000 yr. Samples from elevations $<1200 \mathrm{~m}$ are from tufa mounds that may have acquired radioactively dead carbon from ground water. Dashed lines indicate conjectured trajectories of lake-level rise and fall. 
chara and diatom deposits in the Astor Pass area indicates a decline in lake level to $<1252 \mathrm{~m}$ by $\sim 15,500$ yr B.P. [organic carbon from this soil (PL85-3S) has a ${ }^{14} \mathrm{C}$ age of $15,660 \pm 150$ yr B.P.].

\section{2. $15,500-12,400$ yr B.P.}

By 14,500 yr B.P., lakes in all Lahontan subbasins had reached $1308 \mathrm{~m}$ and coalesced; by 13,800 yr B.P., tufa was being precipitated at $1330 \pm \mathrm{m}$. Lake Lahontan began to recede from its highstand by $\sim 13,600$ yr B.P., reaching an elevation of $\sim 1160$ m by 12,400 yr B.P. (Fig. 9 ).

\section{3. $12,400-9000$ yr B.P.}

Between $12,370 \pm 310$ and $12,030 \pm 110$ yr B.P., dolomite precipitation occurred at low elevations $(1160 \pm \mathrm{m})$ around the Pyramid Lake subbasin. A gap in tufa deposition exists between $12,030 \pm 110$ $\mathrm{yr}$ and $10,960 \pm 80 \mathrm{yr}$ B.P. We interpret this gap as indicating that Pyramid Lake fell below 1159 $\mathrm{m}$ during this time interval which was coeval with the Allerod Interstade (Wright, 1989).

Between $10,960 \pm 80$ and $9020 \pm 70$ yr B.P, a 2-cm thick layer of young dense laminated tufa formed between 1159 and $1205 \mathrm{~m}$. The laminated tufa is composed of low-magnesium calcite, indicating precipitation from a relatively fresh-water lake. During this time, young thinolitic and young branching tufas were eroded from the faces of Marble Bluff and Anaho Island between 1207 and $\sim 1225$ m (Benson et al., 1992). Dates on rock varnish coating boulders at an elevation of 1220 $\mathrm{m}$ on Anaho Island indicate that the lake occupied this elevation sometime between 10,850 and 9600 yr B.P. (Benson et al., 1992). The lake-level maximum that occurred at this time was coeval with the Younger Dryas Stade (Mangerud et al., 1974).

\section{4. $9000-0$ yr B.P.}

A gap in tufa deposition exists between $\sim 9000$ and $\sim 5000 \mathrm{yr}$ B.P. For at least part of this time, Pyramid Lake may have been below $1159 \mathrm{~m}$. Encrusting tufas and beachrock (Table 2) formed below $1183 \mathrm{~m}$ (the former elevation of Mud Lake Slough sill, see discussion in Benson, 1994). between $5080 \pm 60$ and $1350 \pm 70$ yr B.P. The relative thinness ( $<1.5-\mathrm{cm}$ thick) of aragonitic encrusting tufas found between 1183 and $1159 \mathrm{~m}$ indicates the possibility that lake level remained below this depth interval during much of the late Holocene.

\section{Change in effective wetness between 30,000 and 0 yr B.P.}

Changes in effective wetness (Table 5), necessary to achieve spill from or to various Lahontan subbasins, were calculated using Eq. 1 and data listed in Table 6. It is impossible to associate a unique value of $\Delta W_{\text {eff }}$ with lake level in the Pyramid Lake subbasin between 1207 and $1308 \mathrm{~m}$ because of the possibility of river diversion (Benson and Paillet, 1989).

Values of $\Delta W_{\text {eff }}$ (Table 5) achieved by Lake Lahontan are indicated in Fig. 10. At 23,000 yr

Table 6

Surface areas $\left(\mathrm{km}^{2}\right)$ of Lahontan subbasins for some elevations (m). Data taken from Benson and Mifflin (1986)

\begin{tabular}{|c|c|c|c|c|c|c|c|}
\hline Elevation & $\begin{array}{l}\text { Pyramid } \\
\text { Lake } \\
\text { subbasin }\end{array}$ & $\begin{array}{l}\text { Winnemucca } \\
\text { Lake } \\
\text { subbasin }\end{array}$ & $\begin{array}{l}\text { Smoke Creek- } \\
\text { Black Rock } \\
\text { Desert subbasin }\end{array}$ & $\begin{array}{l}\text { Carson } \\
\text { Desert } \\
\text { subbasin }\end{array}$ & $\begin{array}{l}\text { Honey } \\
\text { Lake } \\
\text { subbasin }\end{array}$ & $\begin{array}{l}\text { Buena } \\
\text { Vista } \\
\text { subbasin }\end{array}$ & $\begin{array}{l}\text { Walker } \\
\text { Lake } \\
\text { subbasir }\end{array}$ \\
\hline 1177 & 568 & 256 & - & - & - & - & - \\
\hline 1207 & 680 & 337 & 2514 & - & - & - & - \\
\hline 1222 & 721 & 365 & 3066 & - & 535 & - & - \\
\hline 1225 & 728 & 370 & 3139 & - & 543 & - & - \\
\hline 1265 & 836 & 436 & 5809 & 5580 & 1140 & 505 & - \\
\hline 1308 & 1003 & 517 & 8407 & 6846 & 1606 & 710 & 781 \\
\hline 1335 & 1126 & 569 & 9152 & 8325 & 1692 & 812 & 1100 \\
\hline
\end{tabular}




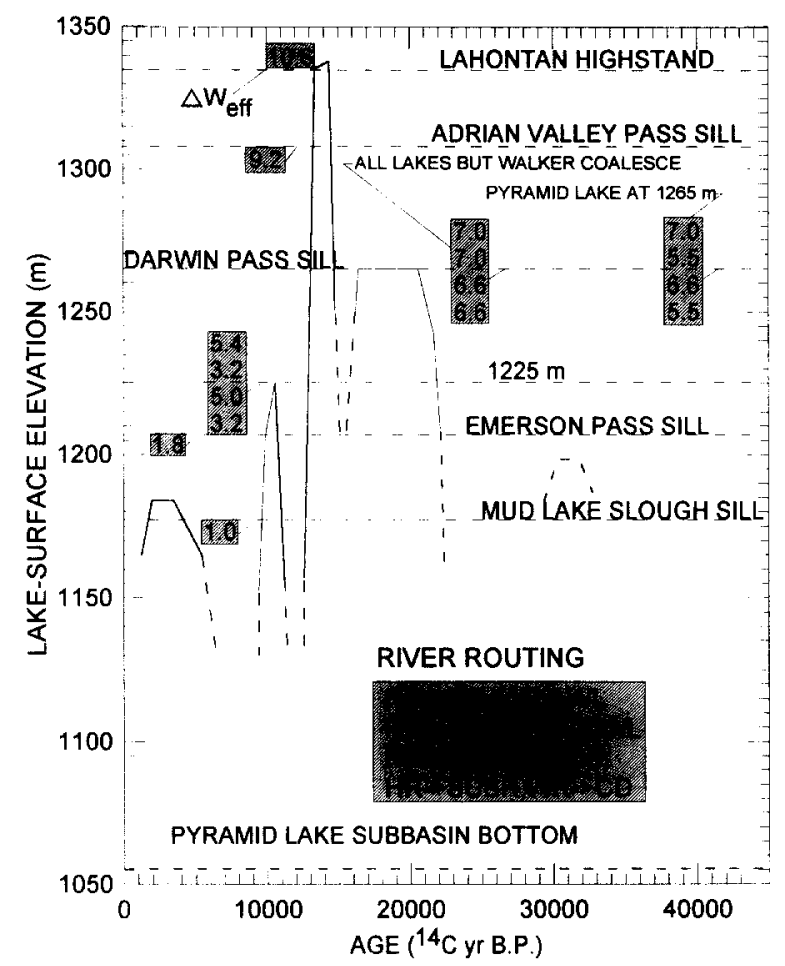

Fig. 10. Values of effective wetness $\left(\Delta w_{\text {eff }}\right)$ associated with sill levels (spill points) and the 1225 -m elevation in western Lahontan subbasins. When more than one value of $\Delta w_{\text {cff }}$ is listed, the uppermost number was calculated for a situation in which the Humboldt River $(H R)$ flows to the Carson Desert subbasin $(C D)$ and the Walker River (WR) flows to Walker Lake $(W L)$. The second number indicates a calculation made when HR flows to the Smoke Creek-Black Rock Desert subbasin $(B R D)$ and WR flows to WL. The third number indicates a calculation made when HR flows to $C D$ and WR flows to $C D$, and the fourth number indicates a calculation made when HR flows to BRD and WR flows to CD. When lakes in the western Lahontan subbasins reach $1265 \mathrm{~m}$, either they spill into the Carson Desert $\left(\Delta w_{\text {eff }}=5.5\right)$ or they coalesce with Carson Lake $\left(\Delta w_{\text {eff }}=6.6-7.0\right)$ depending on the paths of the Lahontan rivers.

B.P., $\Delta W_{\text {eff }} \leqslant 1.0$. When the western Lahontan subbasins first spilled to the Carson Desert subbasin, $\Delta W_{\text {eff }}=5.5-7.0$ (if the Humboldt River flowed to the Black Rock Desert). When the lakes in all subbasins excepting Walker Lake subbasin coalesced at $1265 \mathrm{~m}, \Delta W_{\text {eff }}$ had a value of either 6.6 (Walker River flowed to Walker Lake) or 7.0 (Walker River flowed to the Carson Desert). The Lahontan highstand occurred when $\Delta W_{\text {eff }}=10.6$.
If the Humboldt River diverted from the Black Rock Desert to the Carson Desert after the Lahontan highstand and the Walker River flowed to Walker Lake, $\Delta W_{\text {eff }}$ was of the same magnitude $\sim 10,500$ yr B.P. $\left(\Delta W_{\text {eff }}=5.4\right)$ as it was when the lakes in the western Lahontan subbasins first reached $1265 \mathrm{~m}$. During the late Holocene, $\Delta W_{\text {eff }} \approx 1.0$.

\section{The Lahontan lake-level record as an indicator of the position of the polar jet stream}

Antevs (1938) was the first to link maximum levels of northern Great Basin lakes to the presence of a permanent ice sheet over North America, hypothesizing that the size of the ice sheet, combined with a permanent high-pressure area located over it, caused storm tracks to be pushed south of their present "normal" paths over northern Nevada and Utah. Renewed interest in this concept occurred in the mid 1980s when experiments using atmospheric general circulation models (Manabe and Broccoli, 1985; Kutzbach and Wright, 1985; Kutzbach and Guetter, 1986) indicated that glacial-age boundary conditions, including the size and shape of Laurentide Ice Sheet, were sufficient to produce the effect that Antevs had hypothesized. When the ice sheet was at a maximum (21,000-17,000 yr ago, Fig. 11), zonal flow aloft occurred across North America and the North Atlantic. The mean position of the southern branch of the jet stream lay south of the Lahontan basin in winter and over its northern edge in summer. Under these conditions of extensive cloudiness, decreased air temperature, and increased precipitation, lakes in the Lahontan basin increased in size (Hostetler and Benson, 1990).

With reductions in size and elevation of the ice sheet, the two branches of the jet stream recombined. Flow aloft became meridional and the paths of the winter and summer jet streams remained north of the Lahontan basin. Climate of the Lahontan basin became dry and warm and lake levels declined. During solar forced growth and decay of the Laurentide Ice Sheet, Lake Lahontan should have experienced two lake-level maxima corresponding to the pre- and post-maximum gla- 


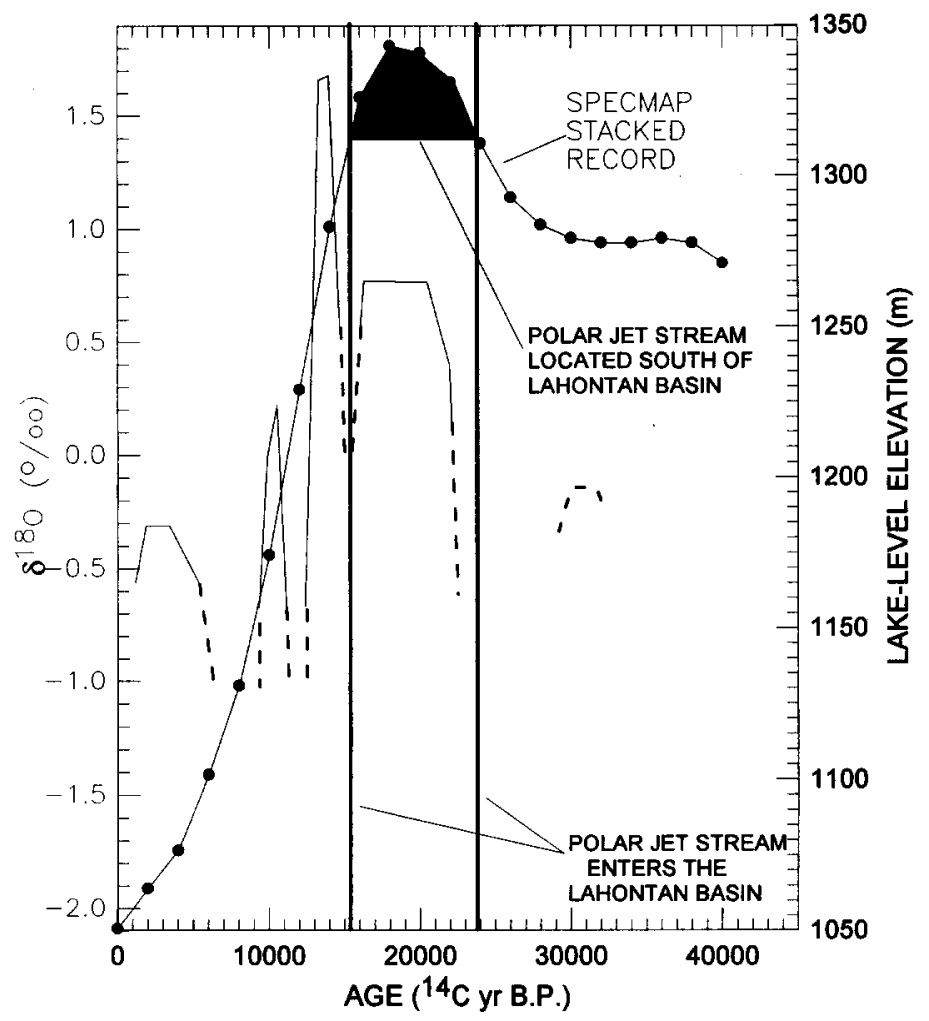

Fig. 11. A comparison of the SPECMAP stacked marine $\delta^{18} \mathrm{O}$ record (Imbrie et al., 1984) with the Lahontan lake-level envelope. The marine $\delta^{18} \mathrm{O}$ record is a proxy for the amount of ice stored in the world's glaciers. Increasing values of marine $\delta^{18} \mathrm{O}$ indicate increasing amounts of stored ice. The major increases in lake level that occur at $\sim 23,500$ and 15,500 yr B.P. are associated with a $\delta^{18} \mathrm{O}$ value of $\sim 1.4$. We believe that this particular value is indicative of an ice sheet whose size and shape is sufficient to force the polar jet stream over the Lahontan basin. When the core of the jet stream overlies the basin (Laurentide Ice Sheet is increasing in size), increases in cloudiness and rainfall and decreases in air temperature occur. When the core of the jet stream lies south of the basin (during maximum extent of Laurentide Ice Sheet), the basin is still cold and cloud covered, but much of the increased precipitation associated with the jet stream core falls south of the basin. When the core of the jet stream lies north of the basin (Laurentide Ice Sheet has retreated), the climate becomes less cloudy, warm, and arid.

cial passages of the jet stream core over the Lahontan basin. This concept is borne out by evidence that Lake Lahontan abruptly increased in size starting $\sim 23,500$ and $\sim 15,500$ yr B.P. (Fig. 11) when the globally integrated $\delta^{18} \mathrm{O}$ value of seawater was $1.4 \%$ (Imbrie et al., 1984). The assumption made here is that the globally integrated $\delta^{18} \mathrm{O}$ value of seawater is a reasonable proxy, not only for world-wide ice volume, but also for volume of the Laurentide Ice Sheet.

The abruptness of the two lake-level rises is hypothesized to reflect the encounter of precipitation maxima, located near the jet-stream core (Starrett, 1949), with the Lahontan basin.
Differences in elevations of the two lake-level maxima were due to differences in the residence times of the jet stream over the Lahontan basin and differences in the initial sizes of the lakes. When the jet stream core passed over the lake $\sim 23,500$ yr ago, the lake was small; however, when the jet stream moved northward over the lake in response to reduction in size of the Laurentide Ice Sheet $\sim 15,500$ yr ago, the lake was already relatively large.

Some of the major features in the Lahontan lake-level envelope cannot be explained by solarforced changes in the size of the Laurentide Ice Sheet; e.g., the lake-level oscillation between 11,000 
and 10,000 yr B.P. and the lake-level minima at $\sim 15,500$ yr B.P. An explanation of these phenomena is beyond the scope of this paper.

\section{A comparison of the Lake Lahontan and Lake Bonneville lake-level records}

Lake Bonneville's drainage lay to the west of and on about the same latitude as Lake Lahontan's drainage. We would, therefore, expect that the hydrologic balances of Lake Bonneville and Lake Lahontan would covary with movement of the polar jet stream. A lake-level envelope for the Bonneville basin between 32,000 and 0 yr B.P. (Fig. 12) was constructed using data presented in Oviatt et al. (1992). Values of $\Delta W_{\text {eff }}$ calculated from the hypsographic data of Currey et al. (1984) have also been affixed to the lake-level envelope (Fig. 12). Lake Bonneville was at low levels

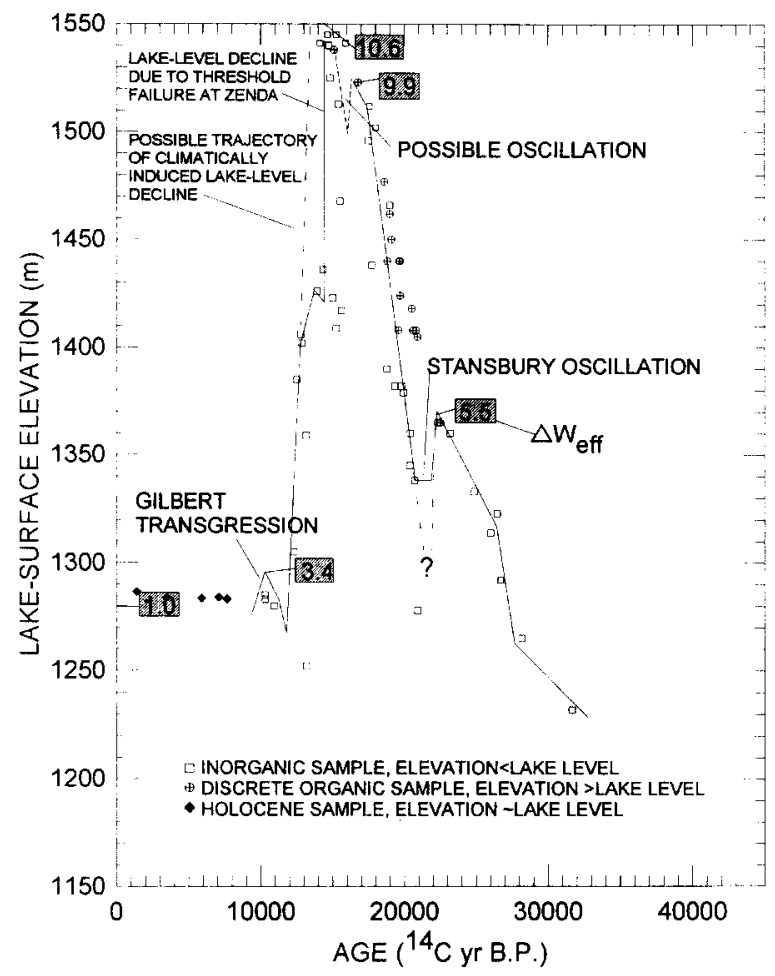

Fig. 12. Lake Bonneville record for the past $30,000 \mathrm{yr}$. Values of effective wetness $\left(\Delta w_{\text {eff }}\right)$ are indicated in shaded squares. Data for this figure were taken from Oviatt et al. (1992). between 32,000 and 27,000 yr B.P. After $27,000 \mathrm{yr}$ B.P. the lake rose reaching its highest level by $\sim 15,000$ yr B.P. Two oscillations (lake-level minima) occurred at $\sim 21,000$ and $\sim 16,000$ yr B.P. The minimum elevation of the Stansbury oscillation remains somewhat conjectural (Oviatt et al., 1990; Thompson et al., 1990). The elevation $(\sim 1340 \mathrm{~m})$ of the solid line at $21,000 \mathrm{yr}$ B.P. is based on the lowest occurrence of a shallow-water sand associated with the oscillation (Oviatt et al., 1990).

The magnitude and timing of the 16,000 yr B.P. oscillation (Keg Mountain oscillation) also remains in doubt. The Keg Mountain oscillation was originally hypothesized to have consisted of a 45- $\mathrm{m}$ decline in lake level, with the lowest point of the oscillation being achieved immediately prior to the eruption of the Pahvant Butte ash (Currey and Oviatt, 1985). A recent reevaluation of the evidence for the Keg Mountain oscillation indicates that a transgressive phase oscillation of lesser magnitude could also explain the stratigraphic sequence found at its type locality (Oviatt et al., 1994). Existing evidence indicates that the lower limit of the Keg Mountain oscillation was $\sim 1500$ m (Oviatt et al., 1994).

Lake Bonneville receded from its highest shoreline as the result of the catastrophic downcutting of the basin margin $\sim 14,500$ yr B.P. For this reason, we do not know what elevation Lake Bonneville would have achieved after 14,500 yr B.P. or when it would have fallen in response to the northward movement of the polar jet stream. A dashed line indicating the possible timing of the climatic induced fall of Lake Bonneville is shown on Fig. 12. At $\sim 12,000$ yr B.P., Great Salt Lake was at very low levels and a subsequent transgression of Great Salt Lake to the Gilbert shoreline culminated between 10,900 and 10,300 yr B.P. (Currey, 1990).

The Lahontan and Bonneville chronologies compare reasonably well in terms of the timing of lake-level decline and fall and in terms of effective wetness between $\sim 21,000$ and 9000 yr B.P. (Figs. 10 and 12). Lake Bonneville appears to have risen more rapidly between 21,000 and 16,500 yr B.P. than Lake Lahontan, achieving a $\Delta W_{\text {eff }}$ of 9.9. The $\Delta W_{\text {eff }}$ of the Lahontan system was between 
5.5 and 7.0 at 16,500 yr B.P. (Fig. 10). Both lake systems recorded a decrease in level of uncertain magnitude at $\sim 16,000$ yr B.P. Given the uncertainty in the timing of the climatically induced fall of Lake Bonneville, both lakes can be hypothesized to have begun receding at $\sim 13,000$ yr B.P. Both lake systems experienced low levels at $\sim 12,000 \mathrm{yr}$ B.P. and both lakes also experienced a final lakelevel transgression that resulted in higher levels at $\sim 10,500$ yr B.P. Age and elevation control for both lake systems prior to $22,000 \mathrm{yr}$ B.P. is too inaccurate and too discontinuous to permit a meaningful comparison of the two systems. However, the covariance in lake-level variation after 22,000 yr B.P. suggests that both systems were responding nearly synchronously with variation in the positon of the polar jet stream.

\section{Summary and conclusions}

Most tufas in the Pyramid Lake subbasin, including the large mound formations that border the existing lake, were deposited within the last 35,000 yr. Tufa deposition in the Holocene was discontinuous in time and small in magnitude. Older (>21,000 yr B.P.) tufas (old tubular and old branching tufas) probably were deposited in association with ground-water discharge; thus, their ${ }^{14} \mathrm{C}$ ages should be considered maximum estimates of their time of formation.

The Lahontan lake-level envelope developed from tufa elevations and ${ }^{14} \mathrm{C}$ ages indicates the following: (1) for at least part of the time between $\sim 27,500$ and 23,500 yr B.P., Lake Lahontan was at a low elevation $(\sim 1165 \mathrm{~m}) ;(2)$ by $\sim 21,000 \mathrm{yr}$ B.P., Lake Lahontan had reached the elevation of Darwin Pass Sill and remained near this elevation $(1265 \mathrm{~m})$ for the next $5000 \mathrm{yr}$; (3) Lake Lahontan fell below an elevation of $1252 \mathrm{~m}$ by $\sim 15,500 \mathrm{yr}$ B.P.; (4) by 14,500 yr B.P., lakes in all Lahontan subbasins had reached $1308 \mathrm{~m}$ and had coalesced; (5) by 13,800 yr B.P., Lake Lahontan achieved its last highstand (>1330 m), and at 13,600 yr B.P., it began to recede; (6) by 12,400 yr B.P., Lahontan had receded to an elevation of $\sim 1160 \mathrm{~m}$; (7) between 12,000 and 11,000 yr B.P., Lake Lahontan probably remained below $1160 \mathrm{~m}$; (8) between
11,000 and 9000 yr B.P., Lake Lahontan experienced a profound oscillation in level, rising to an elevation of $\sim 1225 \mathrm{~m}$ by 10,500 yr B.P.; (9) between $\sim 9000$ and $\sim 5000$ yr B.P., no lake level data exist; and (10) between 5000 and $1400 \mathrm{yr}$ B.P., lake level remained at or below $1183 \mathrm{~m}$, the early Holocene elevation of the spill point to the Winnemucca Lake subbasin.

Much of the carbonate in the mound complexes was deposited between 30,000 and 12,000 yr B.P. This time interval is essentially synchronous with the last major lake cycle in the Lahontan basin, indicating that ground- and surface-water discharge varied together during the last last cycle.

\section{Acknowledgments}

My appreciation is expressed to those who reviewed earlier versions of this manuscript including James Bischoff, Ted McConnaughey, and Robert Rye of the U.S. Geological Survey. I also thank the Pyramid Lake Paiute Tribal Council for access to the Pyramid Lake Reservation. Charles "Jack" Oviatt of Kansas State University and Kerry Kelts of the University of Minnesota provided thoughtful reviews of the final manuscript.

This work was performed in part under the auspices of the US Department of Energy by Lawrence Livermore National Laboratory under contract W-7405-ENG-48.

\section{References}

Antevs, E., 1938. Postpluvial climatic variations in the southwest. Bull. Am. Meteorol. Soc., 19: 190-193.

Benson, L.V., 1978. Fluctuation in the level of pluvial Lake Lahontan during the last 40,000 years. Quat. Res., 9: 300-318.

Benson, L.V., 1993. Factors affecting ${ }^{14} \mathrm{C}$ ages of lacustrine carbonates: timing and duration of the last highstand lake in the Lahontan Basin. Quat. Res., 39: 163-174.

Benson, L.V., 1994a. Carbonate deposition, Pyramid Lake Subbasin, Nevada: 1. Sequence of formation and elevational distribution of carbonate deposits (Tufas). Palaeogeogr. Palaeoclimatol. Palaeoecol., 109: 55-87.

Benson, L.V. and Mifflin, M.D., 1986. Reconnaissance bathymetry of basins occupied by Pleistocene Lake Lahontan, 
Nevada and California. U.S. Geol. Surv. Water-Resour. Invest. Rep., 85-4262, 14 pp.

Benson, L.V. and Paillet, F.L., 1989. The use of total lakesurface area as an indicator of climatic change: examples from the Lahontan basin. Quat. Res., 32: 262-275.

Benson, L.V. and Thompson, R.S., 1987. Lake-level variation in the Lahontan Basin for the past 50,000 years. Quat. Res., 28: 69-85.

Benson, L.V., Currey, D., Lao, Y. and Hostetler, S., 1992. Lake-size variations in the Lahontan and Bonneville basins between 13,000 and $9000{ }^{14} \mathrm{C}$ yr B.P. Palaeogr., Palaeoclimatol., Palaeoecol., 95: 19-32.

Currey, D.R., 1990. Quaternary paleolakes in the evolution of semidesert basins, with special emphasis on Lake Bonneville and the Great Basin, U.S.A. Palaeogeogr. Palaeoclimatol. Palaecol., 76: 189-214.

Berger, G.W., 1991. The Use of Glass for Dating Volcanic Ash by Thermoluminescence. J. Geophys. Res., 96: 19,705-19,720.

Bischoff, J.L., Fitzpatrick, J.A. and Rosenbauer, R.J., 1993. The solubility and stabilization of ikaite $\left(\mathrm{CaCO}_{3} \cdot 6 \mathrm{H}_{2} \mathrm{O}\right)$ from $0^{\circ}$ to $25^{\circ} \mathrm{C}$ : Environmental and paleoclimatic implications for thinolite tufa. J. Geol., 101: 21-33.

Broecker, W.S. and Kaufman, A., 1965. Radiocarbon chronology of Lake Lahontan and Lake Bonneville II, Great Basin. Geol. Soc. Am. Bull., 76: 537-566.

Broecker, W.S. and Walton, A.F., 1959. The geochemistry of ${ }^{14} \mathrm{C}$ in freshwater systems. Geochim. Cosmochim. Acta, 16: $15-38$

Currey, D.R. and Oviatt, C.G., 1985. Durations, average rates, and probable causes of Lake Bonneville expansions, 32,000 to 10,000 years ago. In: P.A. Kay and H.F. Diaz (Editors), Problems of and Prospects for Predicting Great Salt Lake Levels. Cent. Public Affairs Adm., Univ. Utah, Salt Lake City, pp. 9-24.

Currey, D.R., Atwood, G. and Mabey, D.R., 1984. Major levels of Great Salt Lake and Lake Bonneville. Utah Geol. Min. Surv. Map 73.

Dansie, A., Davis, J.O, and Stafford Jr., T.W., 1990. The Wizards beach recession: Farmdalian $(25,500$ year BP) vertebrate fossils co-occur with early Holocene artifacts. In: J.A. Willig, C.M. Aikens and J.L. Fagan (Editors), Early Human Occupation in Far Western North America: the Clovis-Archaic Interface. Nev. State Mus. Anthropol. Pap., 21: $153-200$.

Davis, J.O., 1978. Quaternary tephrochronology of the Lake Lahontan area, Nevada and California. Nev. Archeol. Surv. Pap., 7, 123 pp.

Davis, J.O., 1982. Bits and pieces; The last 35,000 years in the Lahontan area. In: D.B. Madsen and J.F. O'Connell (Editors), Man and Environment in the Great Basin. Soc. Am. Archeol. Pap., 2: 53-75.

De Deckker, P. and Last, W.M., 1988. Modern dolomite deposition in continental, saline lakes, western Victoria, Australia. Geology, 16: 29-32.

Erickson III, D.J., 1993. A stability dependent theory for air-sea gas exchange. J. Geophys. Res., 98: 8471-8488.
Hostetler, S.W. and Benson, L.V., 1990. Paleoclimatic implications of the high stand of Lake Lahontan derived from models of evaporation and lake level. Clim. Dyn., 4: 207-217.

Imbrie, J., Hays, J.D., Martinson, D.G., McIntyre, A., Mix, A.C., Morley, J.J., Pisias, N.G., Prell, W.L. and Shackleton, N.J., 1984. The orbital theory of Pleistocene climate: support from a revised chronology of the marine $\delta^{18} \mathrm{O}$ record. In: A. Berger, J. Imbrie, J. Hays, G. Kukla and B. Saltzman (Editors), Milankovitch and Climate, Part 1 (NATO ASI Ser. C, 126). Reidel, Dordrecht, pp. 269-305.

King, G.Q., 1978. The late Quaternary history of Adrian Valley, Lyon County, Nevada. Thesis. Univ. Utah, Salt Lake City, $88 \mathrm{pp}$.

Kutzbach, J.E. and Guetter, P.J., 1986. The influence of changing orbital parameters and surface boundary conditions on climate simulations for the past 18000 years. J. Atmos. Sci., 43: 1726-1759.

Kutzbach, J.E. and Wright Jr., H.E., 1985. Simulation of the climate of 18,000 yr B.P.: Results for the North American/North Atlantic/European Sector and comparison with the geologic record of North America. Quat. Sci. Rev., 4: $147-187$.

Lao, Y. and Benson, L.V., 1988. Uranium-series age estimates and paleoclimatic significance of Pleistocene tufas from the Lahontan basin, California and Nevada. Quat. Res., 30: 165-176.

Manabe, S. and Broccoli, A.J., 1985. The influence of continental ice sheets on the climate of an ice age. J. Geophys. Res., 90: 2167-2190.

Mangerud, J., Andersen, S.T., Berglund, B.E. and Donner, J.J., 1974. Quaternary stratigraphy of Norden, a proposal for terminology and classification. Boreas, 3: 109-128.

Oviatt, C.G., Currey, D.R. and Miller, D.M., 1990. Age and paleoclimatic significance of the Stansbury oscillation of Lake Bonneville, northeastern Great Basin. Quat. Res., 33: 291-305.

Oviatt, C.G., Currey, D.R. and Sack, D., 1992. Radiocarbon chronology of Lake Bonneville, eastern Great Basin, USA. Palaeogeogr. Palaeoclimatol. Palaeoecol., 99: 225-241.

Oviatt, C.G., Sack, D. and Felger, T.J., 1994. Quaternary geologic map of the Old River Bed and vicinity, Millary, Juab, and Tooele Counties, Utah. Utah Geol. Map, 16, 1:62,500, $24 \mathrm{pp}$.

Pauly, H., 1963. Ikaite, a new mineral from Greenland. Arctic, 16: $263-264$.

Shearman, D.J., McGugan, A., Stein, C. and Smith, A.J., 1989. Ikaite, $\mathrm{CaCO}_{3} .6 \mathrm{H}_{2} \mathrm{O}$, precursor of the thinolites in the Quaternary tufas, and tufa mounds of the Lahontan and Mono Lake Basins, western United States. Geol. Soc. Am. Bull., 101: 913-917.

Stafford Jr., T.W., Hare, P.E., Currie, L., Jull, A.J.T. and Donahue, D.J., 1991. Accelerator radiocarbon dating at the molecular level, J. Archaeol. Sci., 18: 35-72.

Starrett, L.G., 1949. The relation of precipitation patterns in North America to certain types of jet streams at the 300-millibar level. J. Meteorol., 6: 347-352. 
Stuiver, M. and Polach, H.A., 1977. Discussion reporting of ${ }^{14} \mathrm{C}$ data. Radiocarbarbon, 19: 355-363.

Thompson, R.S., Benson, L.V. and Hattori, E.M., 1986. A revised chronology for the last Pleistocene lake cycle in the central Lahontan basin. Quat. Res., 25: 1-9.

Thompson, R.S., Toolin, L.J., Forester, R.M. and Spencer, R.J., 1990. Accelerator-mass spectrometer (AMS) radiocarbon dating of Pleistocene lake sediments in the Great Basin. Palaeogeogr. Palaeoclimatol. Palaeoeccol., 78: 301-313.
U.S. Geol. Surv., 1984-1993. Water resources data for Nevada. U.S. Geol. Surv. Water-Data Rep. Ser., Ann. Vol.

Wright Jr., H.E., 1989. The amphi-Atlantic distribution of the Younger Dryas paleoclimatic oscillation. Quat. Sci. Rev., 8: 295-306.

York, D., 1979. Least squares fitting of a straight line with correlated errors. Earth Planet. Sci. Lett., 5: 320-324. 